\title{
Diagenesis and thermal maturity of the Cogollo Group sedimentary rocks in the ANH-CR-Montecarlo-1X well, Cesar-Ranchería Basin, Colombia
}

\author{
Mayra A. Vargas-Escudero ${ }^{1}$, *Carlos A. Ríos-Reyes ${ }^{1}$, Mario García-González ${ }^{1}$, Adriana Ortiz-Orduz ${ }^{1}$ \\ ${ }^{1}$ Escuela de Geología, Universidad Industrial de Santander, Cra 27 Cl 9, Bucaramanga, Colombia. \\ carios@uis.edu.co; mairaleja_18@hotmail.com;mgarciag@uis.edu.co; adriana.ortiz.orduz@gmail.com \\ *Corresponding author: carios@uis.edu.co
}

\begin{abstract}
The exploration well ANH-CR-Montecarlo-1X, in the southern part of the Cesar-Ranchería basin in Colombia, cuts sedimentary rocks assigned to the Cogollo Group (Barremian-Cenomanian). The present study integrates petrographic techniques (thin section microscopy and scanning electron microscopy), geochemistry (total organic carbon and pyrolysis rock-eval) and basic petrophysics to establish the thermal maturity and potential of these rocks as a conventional or unconventional hydrocarbon reservoir. The results of petrographic analysis revealed that the rocks correspond to quartz sandstones and greywackes and the carbonate rocks to mudstones and wackestones. These were affected by diagenetic processes such as compaction and mineral neoformations. The latter include minerals from the clays group that cover the grains of the rock framework, and other types of precipitates, such as silica, ferrous and nonferrous carbonate that cement them. Some of these minerals present partial or total dissolution, for which secondary porosity is recognized. Chloritization and illitization of the argillaceous matrix and feldspars alteration to ferrous and non-ferrous carbonate are also observed, which affects the porosity and permeability of the rock. Additionally, during diagenesis micrite is recrystallized to sparite and carbonate precipitation ocurred in the calcareous rocks. The study also shows that the rocks were more affected by compaction than precipitation of the different types of cement, thus reducing their porosity and permeability. Based on these parameters the siliciclastic rocks in study area have a low potential as conventional reservoir but a good potential as non-conventional reservoir (tight sandstones). The geochemical studies in the calcareous rocks exhibit low content of total organic carbon (between 0 and $4.5 \%$ with an average of $0.71 \%$ ), with kerogens type III and IV. They have high levels of organic matter conversion, indicative that the rocks did generate hydrocarbons, but currently are depleted and in a mature state, compatible with a low potential of hydrocarbon generation.
\end{abstract}

Keywords: Cesar-Ranchería basin, ANH-CR-Montecarlo- $1 X$ well, Cogollo Group, Diagenesis, Non-conventional reservoirs.

RESUMEN. Diagénesis y madurez térmica de las rocas sedimentarias del Grupo Cogollo en el pozo ANH-CR-Montecarlo-1X, Cuenca Cesar-Ranchería Colombia. El pozo de exploración de hidrocarburos ANH-CR-Montecarlo-1X está ubicado en el sector sur de la cuenca Cesar-Ranchería, Colombia. En esta área afloran rocas sedimentarias del Barremiano-Cenomaniano, que se han definido como pertenecientes al Grupo Cogollo. El presente estudio utiliza técnicas petrográficas (microscopía de sección delgada y microscopía electrónica de barrido), geoquímica (evaluación de roca de pirólisis y carbono orgánico total) y petrofísica básica para establecer la madurez térmica y el potencial de estas rocas como reservorios de hidrocarburos convencionales y no convencionales. Los resultados del análisis petrográfico y diagenético indican que las rocas siliciclásticas corresponden a arenisca de cuarzo y grauvacas, en tanto las rocas carbonatadas a fangolitas y wackestone, que se vieron afectadas por procesos diagenéticos como la compactación y neoformación de minerales. Entre estos últimos destacan los del grupo de las arcillas, que cubren los granos que constituyen la roca, y material cementante como la sílice, el carbonato ferroso y no ferroso. Algunos de estos componentes secundarios presentan disolución parcial y/o total, para la cual se reconoce porosidad secundaria. Adicionalmente, se observan procesos de cloritización e illitización de la matriz arcillosa, alteración de feldespatos a carbonato ferroso y no ferroso, recristalización de micrita a esparita y precipitación de carbonato en las rocas calcáreas, todo lo cual afecta la porosidad y permeabilidad de ellas. El estudio también mostró que el proceso de compactación 
es el que tiene el mayor impacto sobre la porosidad y permeabilidad de ellas. Los resultados del estudio de porosidad y permeabilidad indican que las rocas siliciclásticas tienen un bajo potencial como reservorio convencional, pero un buen potencial como reservorio no convencional de hidrocarburos. Los estudios geoquímicos en las rocas calcáreas muestran un contenido de carbono orgánico total entre 0 y $4,5 \%$ con un promedio de $0,71 \%$, con kerógenos tipo III y IV. Las rocas presentan altos niveles de conversión de materia orgánica, lo que indica que estas sí generaron hidrocarburos, pero actualmente están agotadas y en estado de madurez, situación compatible con un bajo potencial de generación de hidrocarburos.

Palabras clave: Cuenca Cesar-Ranchería, Pozo ANH-CR-Montecarlo-1X, Grupo Cogollo, Diagénesis, Reservorios no convencionales.

\section{Introduction}

Due to the hydrocarbon industry growing demand, it is necessary to search for precise and reliable techniques when evaluating a conventional and non-conventional oil system to assess which are generating and reservoirs rocks. In this way, the precise interpretation of sedimentary rocks thermal maturation states becomes important in hydrocarbon exploration (Héroux et al., 1979), as well as the analysis of the spatial distribution and physical properties of hydrocarbon rock reservoirs, which have become one of the main focuses of exploration (Yu et al., 2018). At a global level, research is being carried out on the different types of unconventional hydrocarbon deposits, some of them focused on differentiating them from conventional oil systems. McCarthy et al. (2011) mention that they differ basically in that conventional deposits require the four elements of the petroleum system: generating rock, reservoir rock, trap and seal rock; as well as two processes: oil generation and migration. Another important factor is time, between the processes of migration, the formation of the reservoir rock, trap and seal. On the other hand, non-conventional systems require at least the deposition of the generating rock and sufficient overload to achieve the required thermal maturity; likewise, there are non-generating formations that store hydrocarbons as a result of generating rock formations, although their pores are very poorly interconnected (they have very low permeability) (IAPG, 2019). This last type of deposit is known as tight reservoirs, which generally correspond to non-generating rock formations with very low permeability, which may be storing both oil and gas (tight oil or tight gas), in the same way these can occur in different types of rocks (tight sandstone, tight carbonate). If the hydrocarbons are found in the rock formation in which they were generated and they remained without migrating to permeable formations, they are called tight shale, commonly referred to in the industry as O\&G Shale (e.g., Zou, 2017). There are different techniques for evaluating a conventional or non-conventional petroleum system (e.g., Gómez-Peral, 2008, Rahman and McCann, 2012; Moore, 2013; Schrank and De Ros, 2015; Xi et al., 2015; Lai et al., 2016; Kareem et al., 2017; Rahman and Worden, 2016; Lai et al., 2017; Limarino et al., 2017; Yuan et al., 2017; Haihua et al., 2018; Ma et al., 2018; Mahmic et al., 2018; Gao et al., 2019; Morad et al., 2019). Through petrographic studies the processes of destruction, formation, nature and distribution of the porosities and permeabilities are analyzed. These changes are evidence of the rock diagenetic history, also important since each diagenetic feature produced during the burial and uplift processes of a rock originally porous and permeable affects its quality as a reservoir rock (Sandoval, 2000). In addition to conventional petrography, other analytical techniques used in the reconstruction study of the post-depositional changes, including the determination of the authigenic mineralogical composition, are, among others, scanning electron microscopy analysis (SEM), identifying the types of clay structures, as well as determining the morphology of the pores and their distribution. Also, qualitative elementary analysis can be done using the energy dispersive spectroscopy (EDS) spectra when the morphology of the mineral is not distinguished.

In Colombia, the Cesar-Ranchería basin is a current prospective area for the exploration of unconventional hydrocarbon deposits (National Hydrocarbon Agency, 2019¹), which, together with the Middle Magdalena Valley basin, would considerably increase the country's crude reserves, which currently amount to 1.7 trillion barrels and 4 trillion cubic feet of oil and natural gas, respectively (U.S. Energy Information Administration, 2019²). Estimates made by the Autoridad Nacional de Hidrocarburos (ANH) and the Ministry of Mines and Energy ${ }^{2}$, until 2018,

\footnotetext{
${ }^{1}$ National Hydrocarbon Agency. 2019. Mapa de Áreas (Tierras). https://www.anh.gov.co/hidrocarburos/oportunidades-disponibles/mapa-de-tierras. (Last visited 30/12/2020).

${ }^{2}$ U.S. Energy Information Administration (EIA). 2019. https://www.eia.gov/beta/international/. (Last visited 30/12/2020).
} 
forecast that the country's oil reserves will last for 6.2 years (Ministry of Mines and Energy ${ }^{3}, 2019$ ), The ANH-CR-Montecarlo-1X well, located in the southern sector of the Cesar-Ranchería basin, is the object of the present study (Fig. 1), where among others, the sedimentary rocks of the Cogollo Group outcrop. Previous work carried out in the CesarRanchería basin (e.g., Hernández, 2003; Barrero et al., 2007; Mora et al., 2007; Aguilera et al., 2010; García and Umaña, 2007) stated that the sedimentary rocks of the Cogollo Group depicted different states of thermal maturity. In the same way, and because the rocks of the Cogollo Group present a variety of lithologies (sandstones, limestones and shales) there are discrepancies in terms of which rocks act as generators and reservoirs.

The aim of this work is to study the diagenesis and thermal maturity of the Cogollo Group sedimentary rocks in the ANH-CR-Montecarlo-1X exploration well to assess their potential as reservoir and hydrocarbon generating rocks respectively.

\section{Geological setting}

The Cesar-Ranchería basin, which has an area of $11,630 \mathrm{~km}^{2}$, is located in the northwestern region of Colombia (Fig. 1). Structurally, the tectonic lineaments that limit this basin are the Oca fault

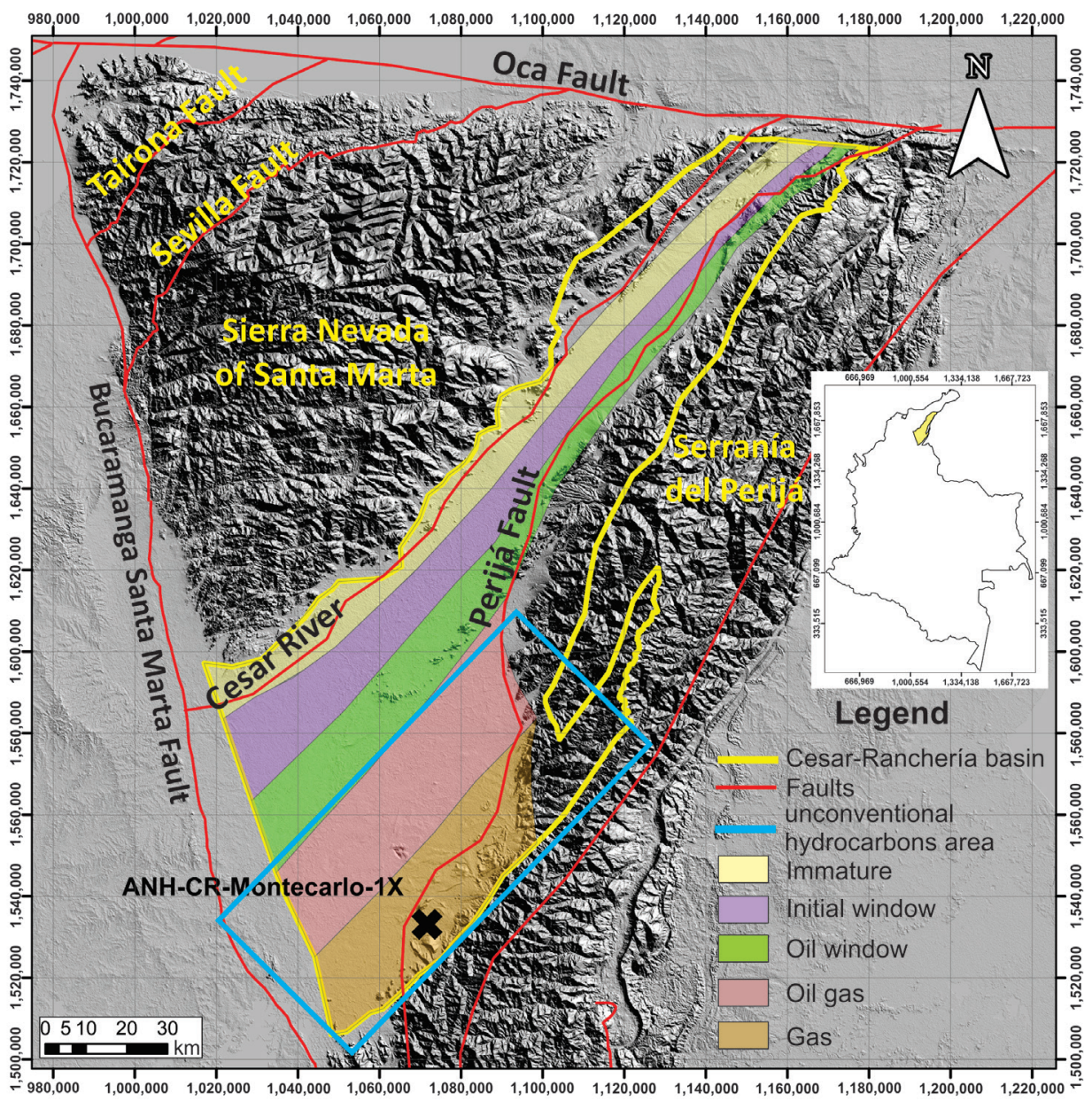

FIG. 1. Geographical localization of the Cesar-Ranchería basin and thermal maturation strips in the Cesar-Ranchería basin. Adapted and modified from Martínez de Vivas et al. (2012). Note the location of the ANH-CR-Montecarlo-1X well (cross in bold) on the overmaturity strip.

${ }^{3}$ Ministry of Mines and Energy. 2019. Avanza la reactivación del sector de hidrocarburos: Suben reservas de petróleo en Colombia a 6,2 años. Continúa desafío en reservas de gas. https://www.minenergia.gov.co/web/guest/historico-de-noticias?idNoticia=24107159. (Last visited 30/12/2020). 
to the north and the Bucaramanga Santa Marta Fault System (BSMF) to the south (Barrero et al., 2007). In addition, as geographic limits, we find the Sierra Nevada of Santa Marta (SNSM) to the west and the Serranía del Perijá (SP) to the east (Fig. 1), which throughout the tectonic/geological evolution influenced the origin of the continental intermountain Cesar-Ranchería basin. These two mountain systems have contrasting lithologies; the SNSM range is made up of metamorphic rocks and the SP comprises sedimentary and volcanosedimentary rocks (Bayona et al., 2007). From the Paleozoic to the Cenozoic the Cesar-Ranchería basin have undergone changes of direction and form, due to different events such as rifting, transpressional and transtensional tectonic deformations, as well as oblique collisions. Consequently, these changes have controlled the distribution, genesis, fillings and tectonic lineaments like in other basins in Colombia (Barrero et al., 2007). Taking into account sedimentological and stratigraphic evidences, García and Umaña (2007) and Vargas (2009) affirm that the Cesar-Ranchería basin is an extension to the northeast of the Middle Magdalena Valley basin, displaced to the north by the Bucaramanga Santa Marta Fault System and separated from the basin of Maracaibo when Serranía de Perijá was raised. The Cogollo Group (Fig. 2), target of this study, is divided into two rock formations denominated Lagunitas and Aguas Blancas, the latter being stratigraphically above. Likewise, the Aguas Blancas Formation is divided into three members (Ánimas, Tucuy and Maracas, Fig. 2). Hernández (2003), described the Ánimas member of the Aguas Blancas Formation as a calcareous mudstone set, made up of carbonaceous black shales, intercalated with black, micritic, carbonaceous limestones with abundant organic matter. The Tucuy member is described as the sandy set, Towards the base it is composed of dark gray sandy siltstones, slightly calcareous, fissile, which locally grade to fine-grained sandstones, with subangular to sub-rounded grains, composed of quartz, with clay matrix and siliceous or calcareous cements. The Maracas member is described as the upper calcareous set, characterized by massive lumaquelic limestones (pelecypods and gastropods). Very similar to Lagunitas Formation, which is composed of fossiliferous thick layers of limestone. The fossils are shells of pelecypods, gastropods, corals and ammonites. According to Hernández (2003), the average thickness of the
Cogollo Group in the Cesar basin is $1,100 \mathrm{~m}$ of which $650 \mathrm{~m}$ correspond to the Maracas $(130 \mathrm{~m})$, Tucuy $(140 \mathrm{~m})$ and Ánimas (380 m) members of the Aguas Blancas Formation and the remaining $450 \mathrm{~m}$ belong to the Lagunitas Formation. The rocks of the Cogollo Group have attributed an age ranging from the Barremian to the Cenomanian and a depositional environment that varies from shallow to a medium marine platform (Hernández, 2003; Mesa and Rengifo, 2011). Several authors (e.g., Hernández, 2003; Barrero et al., 2007; García and Umaña, 2007; García et al., 2009; Mesa and Rengifo, 2011) indicate the Cogollo Group rocks as generating and reservoir rocks in the Cesar-Ranchería basin (Fig. 2). Barrero et al. (2007) associate the Lagunitas and Aguas Blancas Formations as elements of the petroleum system (generating and reservoir rock). Another study conducted by García et al. (2009), suggests that the lower part of the Lagunitas Formation and the Ánimas member of the Aguas Blancas Formation as generating rocks. As reservoir rocks, García et al. (2009) proposes the fractured limestones of the Lagunitas Formation and the sandstones of the Tucuy member of the Aguas Blancas Formation. Geochemical studies by Mora et al. (2007) and Aguilera et al. (2010), where the techniques of TOC, Rock Eval Pyrolysis and organic petrography were used, defined characteristics associated with source rocks for the Ánimas member. Rock Eval Pyrolysis results show good generation potential for these units. Thermal maturity analyzes indicate that it increases with depth, thus the Lagunitas Formation is more mature than the Aguas Blancas Formation. The same authors indicate that the Cogollo Group presents type II kerogens with the potential to generate liquid and gaseous hydrocarbons.

\section{Materials and methods}

In this work an integration of previous data obtained from petrographic techniques such as transmitted light microscopy (e.g., Guzmán-Cardona et al., 2010; Guacaneme, 2011; Montealegre et al., 2013; Lai et al., 2016) and scanning electron microscopy (e.g., Burley and Kantorowicz, 1986; Rahman and McCann, 2012; Kareem et al., 2017; Limarino et al., 2017; Ma et al., 2018; Mahmic et al., 2018), as well as basic petrophysical analyzes (e.g., Guacaneme, 2011; Lai et al., 2016; Yuan et al., 2017) and geochemical techniques such as Total Organic Carbon (TOC) determination and Pyrolysis 


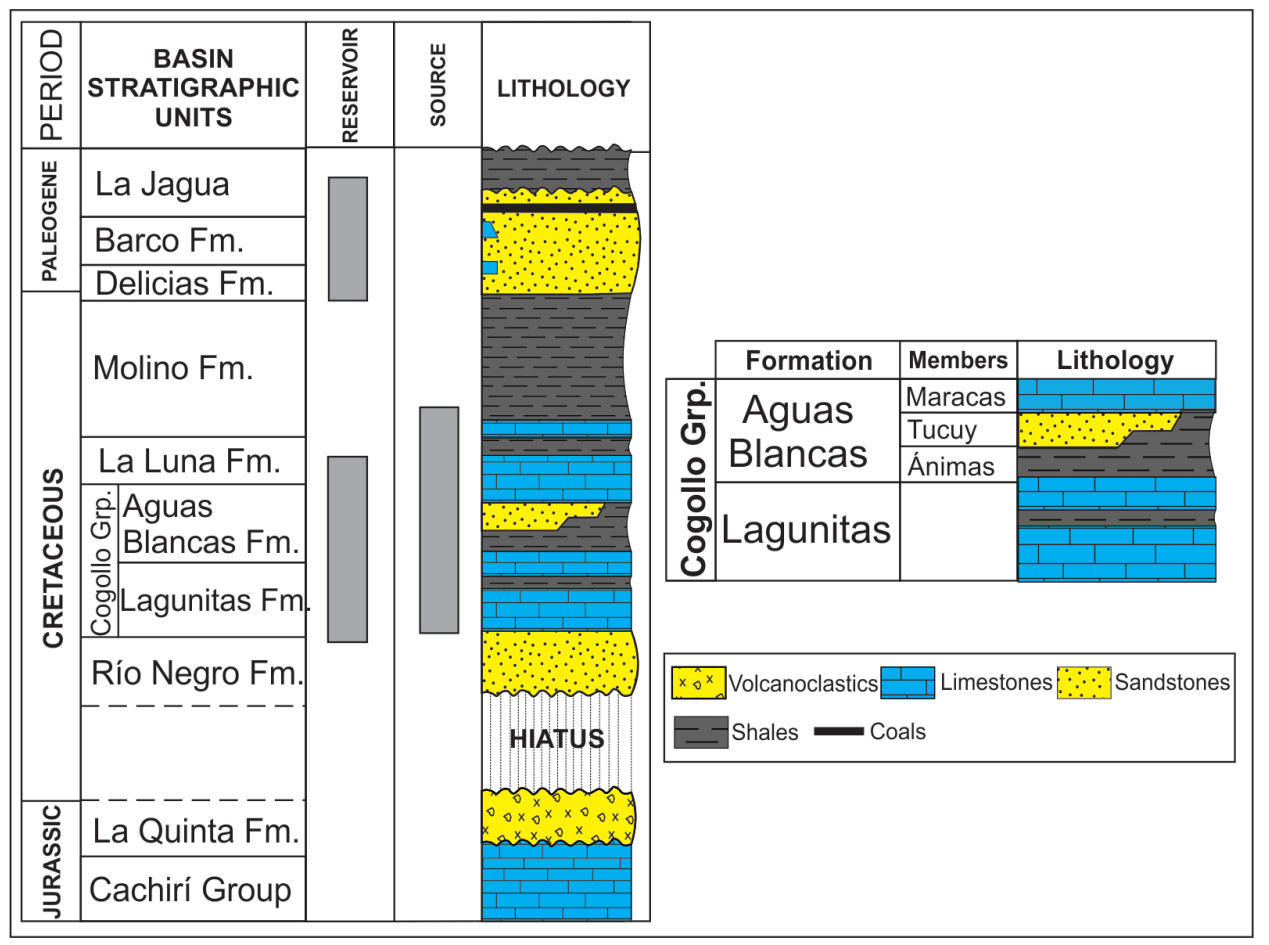

FIG. 2. Oil system chart of the Cesar-Ranchería basin. Adapted and modified from Barrero et al. (2007).

Rock Eval analysis (e.g., Mora et al., 2007; García and Umaña, 2007; García et al., 2009; Aguilera et al., 2010) was carried out with the purpose to study the thermal maturity and potential as a reservoir of the rocks of the Cogollo Group in the ANH-CR-Montecarlo-1X well.

Standard petrography was carried out using a NIKON ECLIPSE E200 transmitted light microscope. Petrographic and diagenetic analysis of 60 thin sections was carried out, out of which 10 corresponded to carbonate rocks and 50 to clastic rocks present in the ANH-CR-Montecarlo-1X well, between the depths of 54 to 1130 feet. For each section, a count of 300 points spaced every $1 \mathrm{~mm}$ was made. For the petrographic analysis, description and classification of both textural and compositional rocks were made using the classifications proposed by Folk (1974) for siliciclastic rocks and Dunham (1962) for carbonate rocks. The diagenesis analysis was performed establishing the main diagenetic products, considering aspects such as interstitial space transformations including the petrographic analysis of porosity and compaction level, mineral neoformations, diagenetic metasomatisms and component transformations. From such data, the diagenetic paragenesis was elaborated, considering the events and the environment in which the different products of the diagenesis originated. SEM images were obtained using a FEI QUANTA FEG 650 Electronic Scanning Microscope under the following analytical conditions: magnification $=800$ 60,000x, WD=5.6-14.0 mm, HV=10.0-20.0 kV, signal $=E T D / Z$ CONT, detector $=$ SE/BSED. On the other hand, elemental semi-quantification was carried out using the EDS/EDAX APOLO X Detector with a resolution of $126.1 \mathrm{eV}$ (in. $\mathrm{Mn} \mathrm{K \alpha}$ ).

\section{Results}

\subsection{Petrography}

The main mineral phases reported in siliciclastic rocks of the Cogollo Group correspond to monocrystalline $(\mathrm{Qm})$ and polycrystalline $(\mathrm{Qp})$ quartz, chert $(\mathrm{Qc})$, opaque $(\mathrm{Op})$ accessory minerals (including pyrite) and organic matter (OM), and the cement is composed of diagenetic minerals among which clay, ferrous (CalFe) and non-ferrous (Calc) calcite and silica (Sil) predominate. Additionally, secondary (S) porosity is reported due to mineral dissolution (Table 1). 
For carbonate rocks, matrix characteristics such as micrite (Mic) content, intraclasts (Intr), pseudosparite (Psp), sparite (Sp), clastic matrix (Clastic) content were considered. Contents of quartz and fossils were also identified (Table 1).

The siliciclastic rocks were classified using the compositional classification diagrams of sedimentary rocks of Folk (1974) for sandstones and greywackes (Fig. 3A, B), where it is shown that most of the siliciclastic rocks present in the ANH-CR-Montecarlo-1X well correspond to sandstones ( $<15 \%$ matrix) of the quartzarenites, subarkoses and sublitharenites type. In smaller proportion, greywackes ( $>15 \%$ matrix) of the type quartzwackes and feldspathic wackes are present. The carbonate rocks were classified using the Folk sedimentary rock classification triangle (1974) (Fig. 3C), where it is shown that the carbonatic rocks present in the ANH-CR-Montecarlo-1X well correspond to impure allochemical and allochemical rocks, and only one sample was classified as an impure orthochemical rock. Using the classification of Dunham (1962) the rocks classify as mudstone, wackestone and in smaller proportion packstone.

\subsection{Diagenesis in siliciclastic rocks}

\subsubsection{Compaction: textural evidence}

Among the evidence of physical compaction are linear contacts that predominate between the clasts, ranging from $40 \%$ to $50 \%$ of total contacts (Fig. 4A, B); concave-convex contacts between 30\% and $40 \%$ (Fig. 4A), sutured contacts ranging from $20 \%$ to $30 \%$ (Fig. 4B) and floating contacts that do not exceed $10 \%$ (Fig. 4A, B). Compaction in the studied rocks is also evidenced by the presence of dissolution pressure structures (stylolites), which were mostly filled with organic matter accompanied by pyrite (Fig. 4C, D).

\subsubsection{Dissolution and secondary porosity}

Porosity is considered low throughout the stratigraphic column in the ANH-CR-Montecarlo$1 \mathrm{X}$ well, but it was observed that secondary porosity increases slightly throughout the well, being higher in the deepest areas (1,033 to $1,326 \mathrm{ft})$ reaching values up to $13 \%$. Secondary porosity is more frequent than primary, with a predominance of dissolution porosity (Fig. 4E, G). Some samples show secondary porosity due to fracture (Fig. 4H). Figure 4I-L shows photomicrographs taken in SEM of some of the types of porosities found in the rocks.

\subsubsection{Cementation}

Different types of cements were identified in the studied siliciclastic rocks such as precipitates of silica cements, which is evidenced by quartz grain with silica overgrowth in optical continuity (Fig. 5A). In addition, to a lesser extent, silt-sized detriltal quartz fragments were observed as part of the interstitial material (Fig. 5B); this fine granular material decreases the permeability of the rock. Minerals of the clays group that cover the sandstone grains were observed in two varieties, as cement of undifferentiated clay minerals filling the interstitial space (Fig. 5C), and as meniscus of cement of clay minerals that can form bridges between grains reducing the permeability of the rocks (Fig. 5D). Clay cement was observed in the well mainly from $700 \mathrm{ft}$ onwards. Anhedral crystals of calcite were observed filling the remaining porosity of the rock (Fig. 5E), some of them with oxidation halos, precipitated in the remaining porous space, occluding the porosity of the rock (Fig. 5F). The non-ferrous carbonate cement was observed dispersed throughout the well. Crystals of ferrous calcite of blue color (due to staining) were found filling the intergranular space (Fig. 5G) and as mosaic of euhedral to equigranular crystals, of ferrous composition, cementing the grains of the framework (Fig. 5H), this cement was observed in few sandstone samples. Chlorite cement filling the interstitial space, leaving intergranular porosity and secondary microcrystalline porosity can be observed (Fig. 5I). Figure 5J shows a chlorite cement filling the remaining intergranular porosity. Aditionally, euhedral (Fig. 5K) and rhombohedric (Fig. 5K) crystals of dolomite are growing at the expense of the rock matrix, anhydrite cement is altering minerals (Fig. 5M) and occluding porosity (Fig. 5N), quartz grains wrapped by leucoxene (Fig. 5O) and disseminated Fe oxides and quartz grains that occur in very fine-grained rocks (Fig. 5P).

SEM images of different types of cement in siliciclastic rocks are illustrated in figure 5Q-X: quartz grain with silica overgrowth in optical continuity (Fig. 5Q); acicular chlorite (Fig. 5R); illite cement (Fig. 5S); illite-smectite cement (Fig. 5T); euhedral crystal of ferrous calcite (Fig. 5U); rhombohedric crystal of dolomite (Fig. 5V); anhydrite cement 


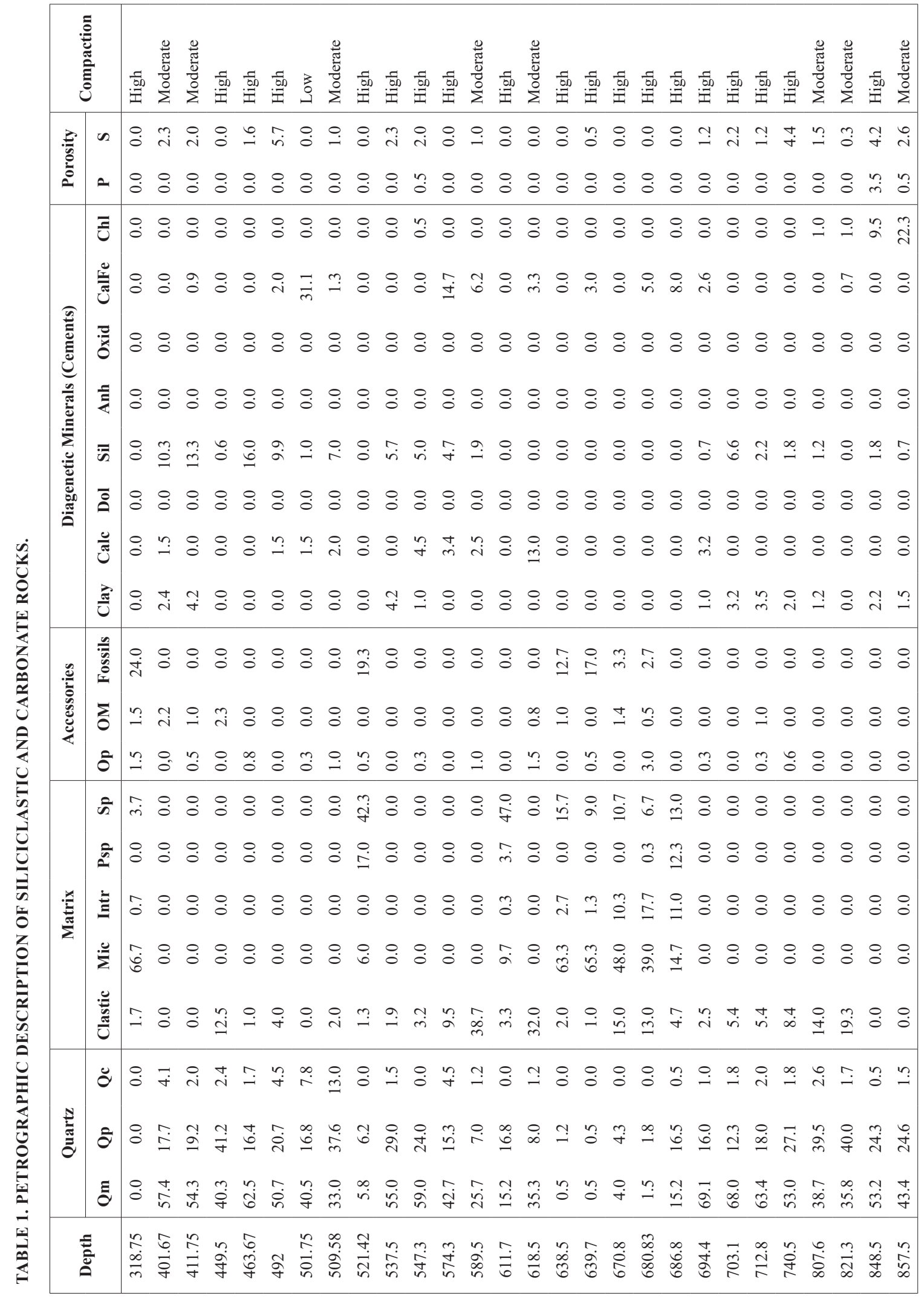




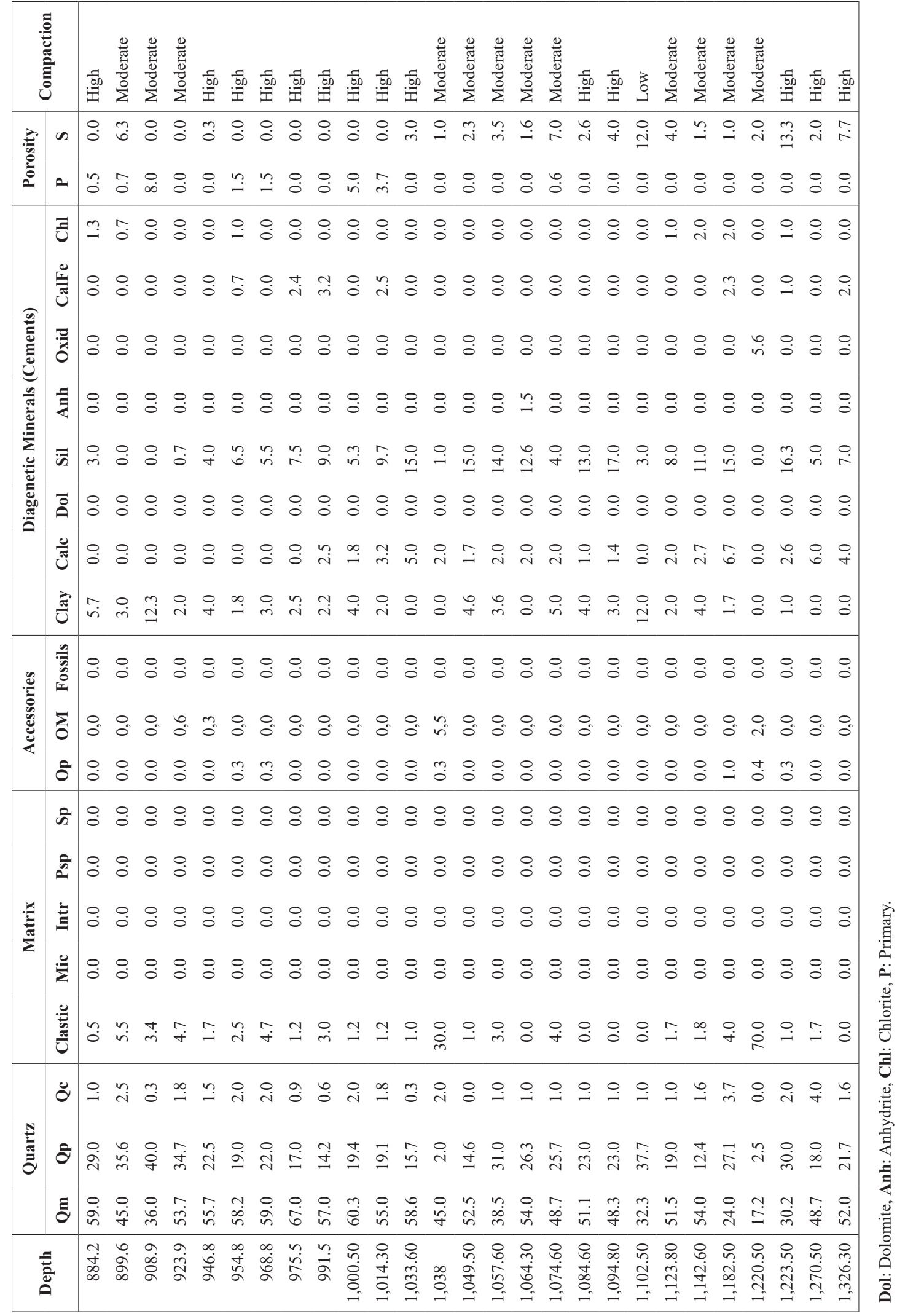




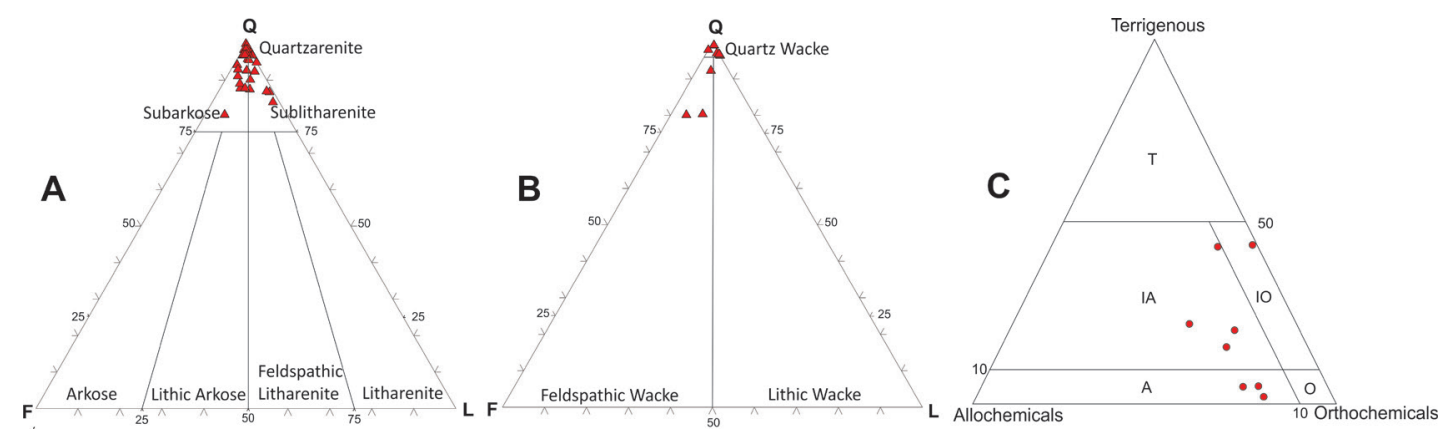

FIG. 3. A. Compositional classification of sandstones and greywackes according to Folk (1974), Quartz (Q), Feldspars (F) and Lithics (L); B. Compositional classification of sedimentary rocks according to Folk (1974); C. Classification for mixed rocks proposed by Folk (1974), according to Allochemical (A), Orthochemical (O), Terrigenous (T), Impure Allochemical (IA) and Impure Ortochemical (IO).
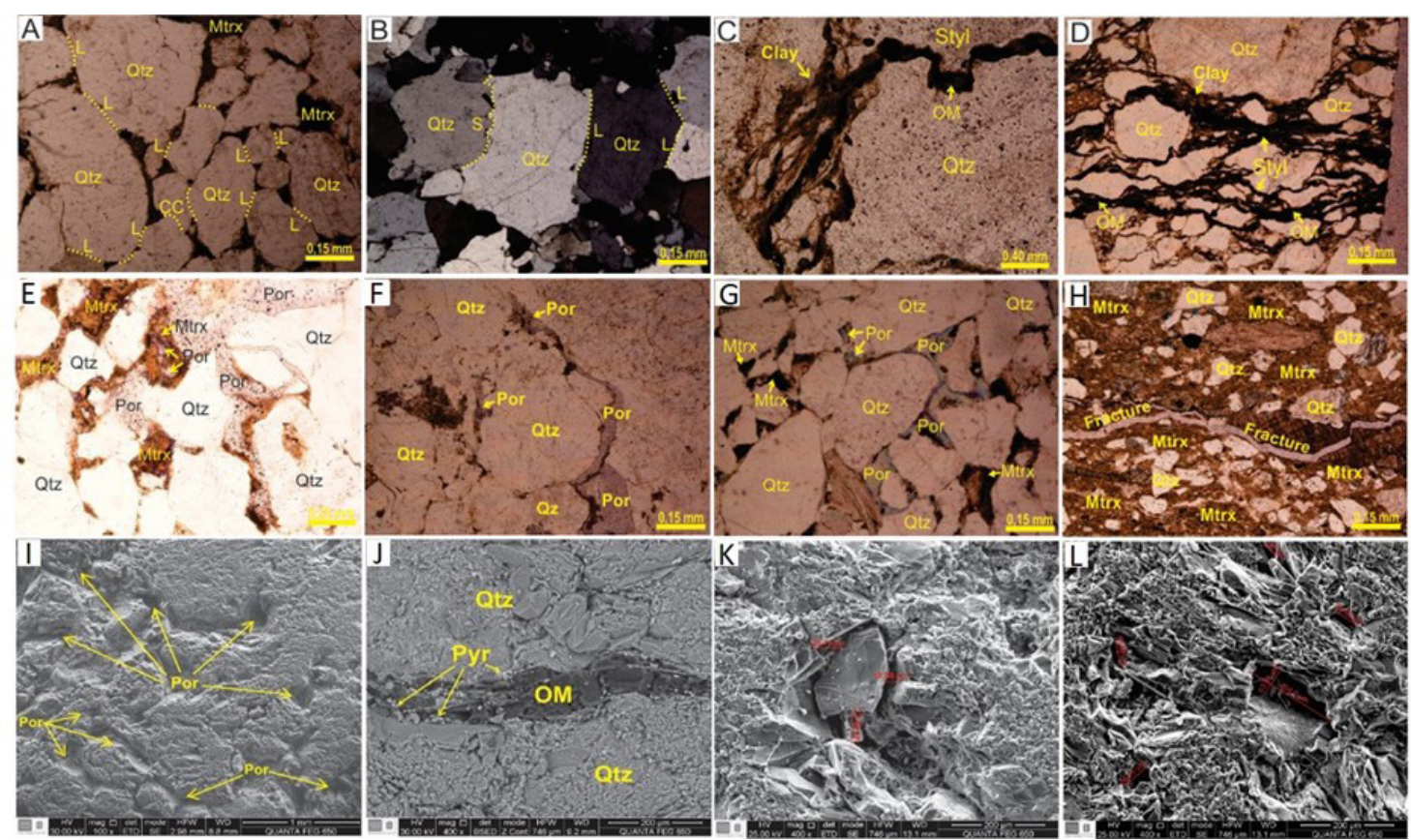

FIG. 4. A-D. Photomicrographs with evidence of compaction in siliciclastic rocks: A. Linear and concave convex type contacts; B. Sutured and linear type contacts; C-D. Stylolites filled with organic matter; E-L. Photomicrographs with evidence of secondary porosity in siliciclastic rocks: E. Secondary porosity generated by the dissolution of interstitial clay minerals; F. Secondary porosity around a quartz grain; G. Intercrystalline secondary porosity generated by the dissolution of interstitial clay minerals. H. Secondary porosity due to fracture; I. SEM images of secondary porosity in siliciclastic rocks affecting the texture of the rock; J. Organic matter filling stylolites, accompanied by pyrite sulphides; K-L. Secondary porosity around a quartz and by dissolution, respectively. Por: porosity; Qtz: quartz; Pyr: pyrite; L: Linear; CC: concave convex; S: sutured; Styl: stylolites; OM: organic matter; Mtrx: matrix.

occluding the porosity of the rock (Fig. $5 \mathrm{~W}$ ); disseminated oxides in clay matrix (Fig. 5X).

The vertical distribution of the different cement types identified in the siliciclastic rocks of the ANH-CR Montecarlo 1X well (Fig. 6) shows that clay and silica cement are present along the whole studied section. However, silica displays a decrease between 600 and $990 \mathrm{ft}$ depth, approximately. A similar pattern is observed for the carbonates. The other types of cement have a restricted distribution. 


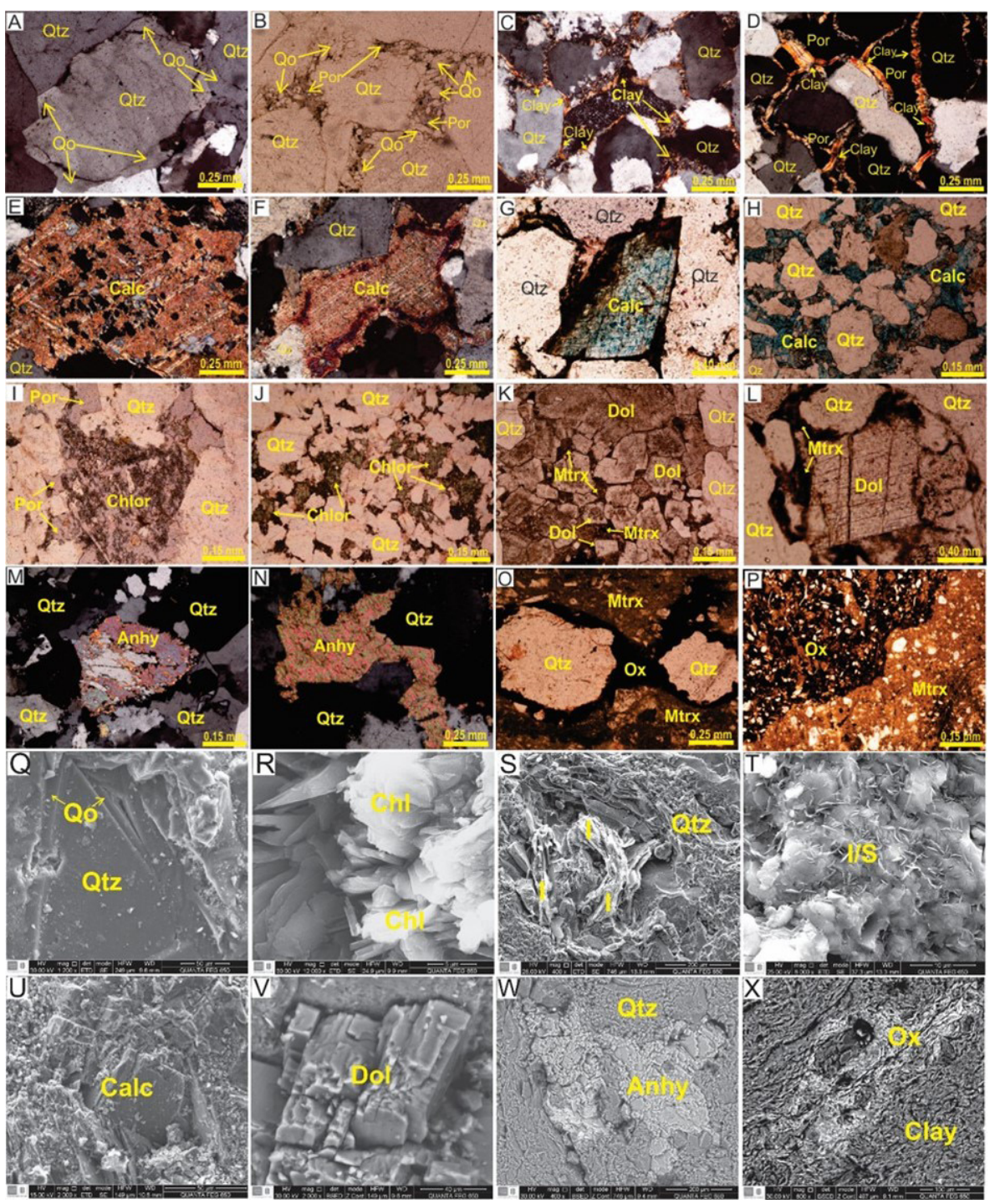

FIG. 5. Photomicrographs with evidence of different types of cement in siliciclastic rocks (A-P) and SEM images (Q-X). Qtz: quartz; Calc: calcite; Dol: dolomite; Chlor: chlorite; I: illite; I/S: illite-smectite; Anhy: anhydrite; Qo: optical continuity; Por: porosity; Ox: oxides; Mtrx: matrix. Clay: undifferentiated clay minerals.

\subsubsection{Metasomatism}

The replacement also called metasomatism involves the dissolution of one mineral and the simultaneous precipitation of another mineral in its place (Morad et al., 2000; Boggs, 2009). Dissolution and reprecipitation can take long periods of time, until the new mineral gradually replaces the previous one (e.g., Sandoval, 2000; Boggs, 2009). The analyzed rocks of the Cogollo Group show replacement reactions involving quartz, carbonates, clay minerals and feldspars.
These include alteration of plagioclase to calcite (Fig. 7A), metasomatism of quartz to non-ferrous carbonate (Fig. 7B), metasomatism of potassium feldspar to ferrous carbonate (Fig. 7C), replacement of plagioclase by ferrous carbonate (Fig. 7D) and to sericite and illite (Fig. 7E), and replacement of the clayed matrix to chlorite (chloritization), illite and illite-smectite (Fig. 7F). According to Boggs (2009), the most characteristic replacement events that occur in sandstones is the replacement of silicate minerals by calcite or dolomite and the 


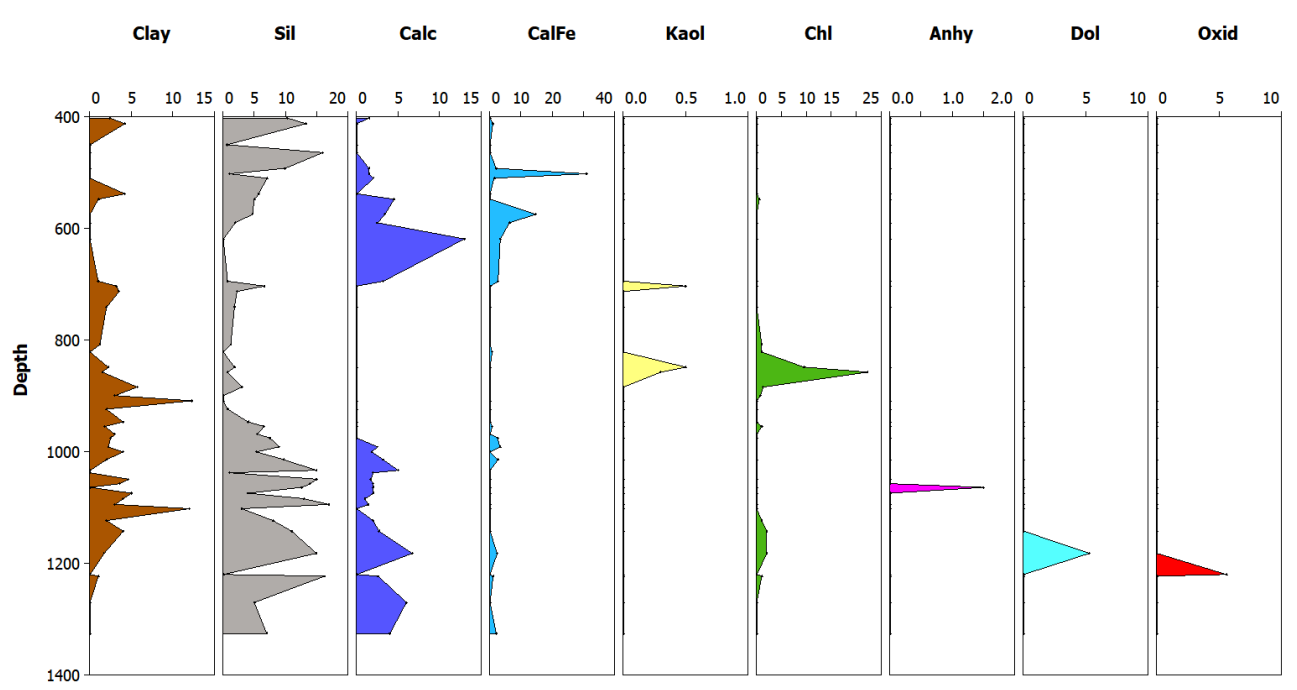

FIG. 6. Vertical distribution of cements in siliciclastic rocks. Depth in feets, cement content in vol.\%.
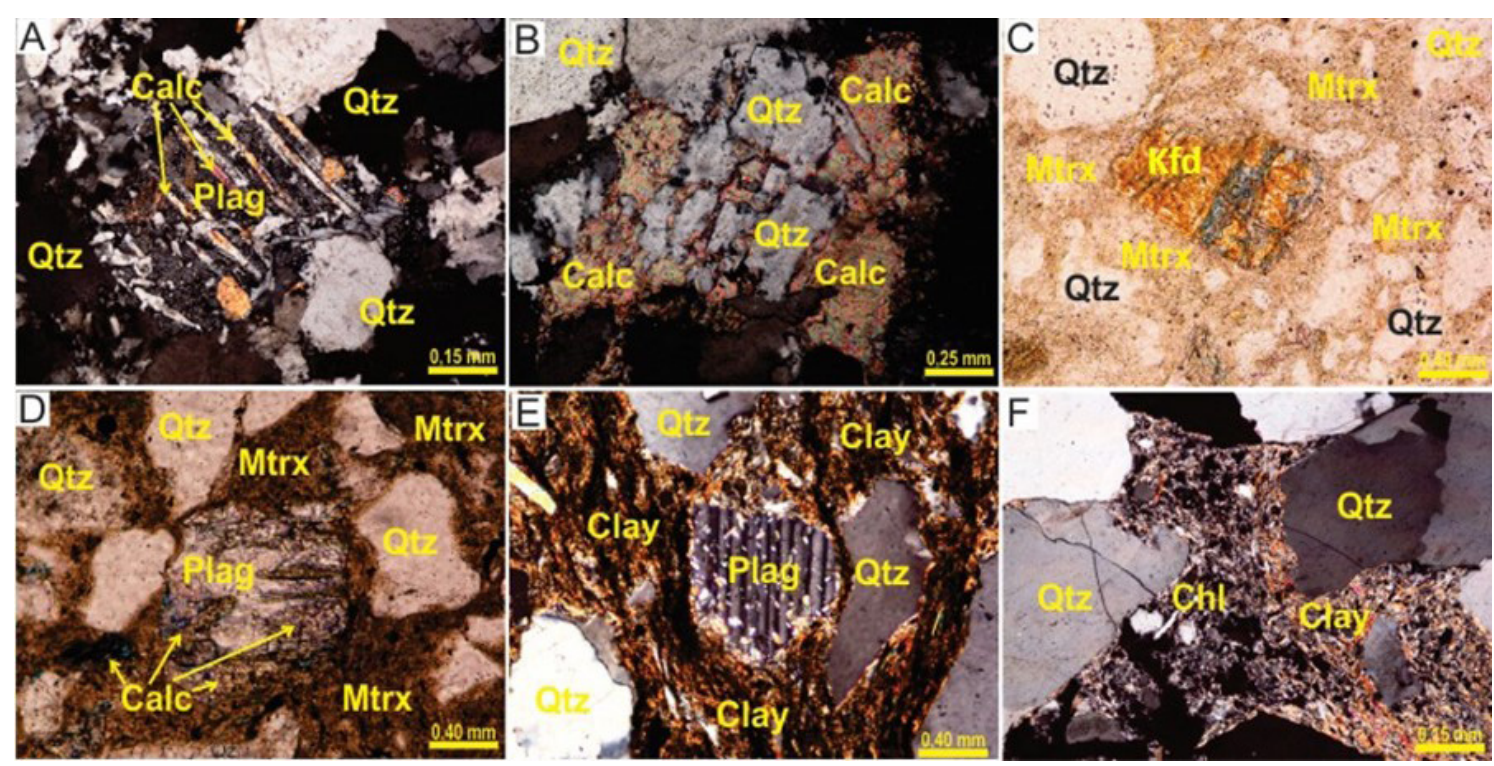

FIG. 7. A-F. Photomicrographs with evidence of different types of metasomatism in siliciclastic rocks. Qtz: quartz; Plag: plagioclase; Kfd: potassium feldspar; Calc: calcite; Chl: chlorite; Mtrx: matrix.

replacement of feldspars with clay minerals. The replacement affects the porosity, mainly when the original minerals are altered to clay, because this is accompanied by an increase in volume, which occludes the porosity, but in turn being a process that involves the dissolution of a mineral may increase porosity (e.g., Worden and Burley, 2003; Boggs, 2009).

\subsection{Diagenesis in carbonate rocks}

\subsubsection{Neomorphism}

Neomorphism processes were evidenced in the recrystallization of the micritic matrix $(<4 \mu \mathrm{m})$ to microspar $(4-10 \mu \mathrm{m})$ and pseudosparite $(10-50 \mu \mathrm{m})$, the sparite was found as equigranular crystals of calcium carbonate predominantly blue, indicating 
iron content and equigranular mosaic of euhedral crystals as a product of fossil shell replacement (Fig. 8A-D). The pseudosparite corresponds to crystals of smaller size than the sparite product of the recrystallization of the matrix of calcareous mud that cements the fossils. The matrix is predominantly of calcareous mud (micrite) although it can have very thin sheets of micritized clay material, which supports a moderate content of fossil allochemical grains, with the presence of disseminated organic matter.

\subsubsection{Cementation}

Cements in carbonate rocks were found in less proportion than in siliciclastic rocks. Nonferrous carbonate, ferrous calcite, oxides and ferruginous cements, mainly hematite, were observed, some of them exhibiting a radial habit. The carbonate cement displays ferrous calcite in polycrystalline aggregates that replace pseudomorphically rhombohedral dolomite (Fig. 8G) and also radial aggregates. Intergrowth of ferreous calcite with clay matrix and quartz grains is observed as well (Fig. 8I, J).

\subsubsection{Dissolution}

The petrographic evidence of porosity in the carbonate rocks is null, because of the muddy material that predominates in the rock matrix. However, evidence of secondary porosity originated by plagioclase dissolution, micritization processes and dissolution of unidentified minerals was found in several of the analyzed samples (Fig. 8K to $8 \mathrm{M})$.
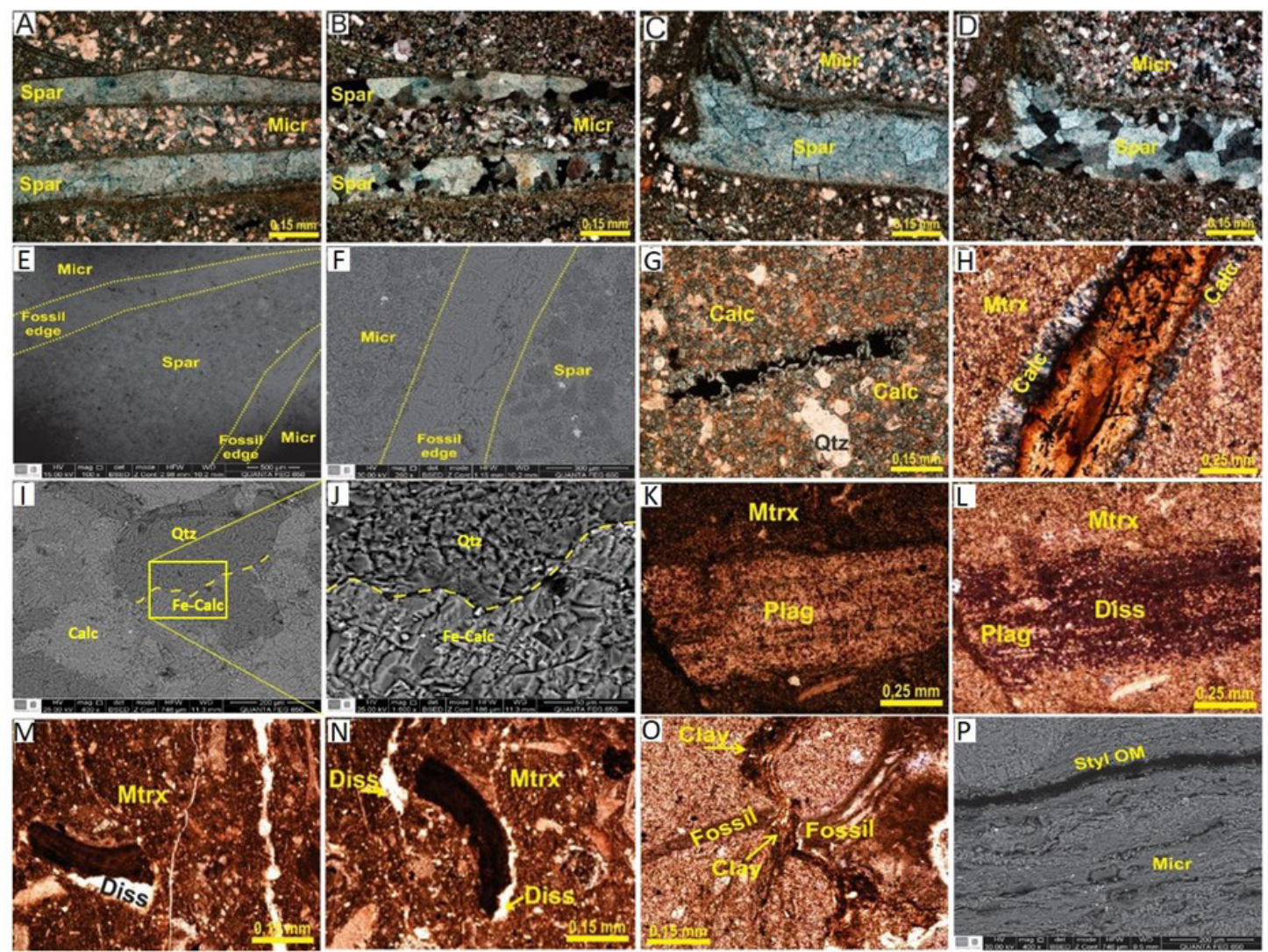

FIG. 8. A-F. Photomicrographs and SEM images with evidence of recrystallization from micrite to sparite inside fossils. G-J. Photomicrographs and SEM images with evidence of cement in carbonate rocks. K-N. Photomicrographs with evidence of porosity in carbonate rocks. O. Photomicrograph of a fossil shell rupture. P. SEM image with evidence of organic matter in carbonate rocks. Styl: Stylolite; OM: organic matter; Micr: micrite; Spar: sparite; Qtz: quartz; Plag: plagioclase; Calc: calcite; Fe-Calc: Fe-rich calcite; Mtrx: matrix; Diss: dissolution. 


\subsubsection{Compaction of carbonate rocks}

Moderate compaction of carbonate rocks is evidenced by: a) deformation of clay matrix sheets and intergranular contacts floating, b) matrix of undifferentiated clay minerals forming sheets parallels to the main stratification of the rock, and with evidence of deformation, c) solution pressure surfaces filled with pyrite and organic matter are observed, d) fossil shell ruptures due to micritization and deformed clay minerals present in the rock matrix (Fig. 80), e) carbonate rocks with stylolite filled with organic matter (Fig. 8P).

\subsection{Basic petrophysical analysis}

The permeability $(\mathrm{mD})$ and porosity (vol.\%) of 104 siliciclastic rock samples, distributed between 401 and 1,326 feet in the ANH-CR-MontecarloIX well, were analized. The porosity ranges from 1.1 to $10.5 \%$ with an average of $4.53 \%$. The permeability ranges from $0.012 \mathrm{mD}$ to $4.884 \mathrm{mD}$ with an average of $0.242 \mathrm{mD}$. They present a positive correlatión (Fig. 9) with increased permeability as porosity increases. Permeabilities lower than 0.1 $\mathrm{mD}$ have porosity ranges of $1 \%$ to $7 \%$. Likewise, permeabilities greater than $0.1 \mathrm{mD}$ have porosity ranges of $3 \%$ to $10 \%$.

Figure 10 shows two diagrams, one of porosity versus depth and another of permeability versus depth, where a slight increase in porosity and permeability is shown as the depth increases. At depths less than $750 \mathrm{ft}$, porosity ranges from $1 \%$ to $6 \%$ and permeability between $0.01 \mathrm{mD}$ and $0.2 \mathrm{mD}$. While at depths greater than $750 \mathrm{ft}$, porosity ranges from $1 \%$ to $10 \%$ and permeability ranges from $0.01 \mathrm{mD}$ to $5 \mathrm{mD}$. Both permeability and porosity behave similarly with increasing depth. They increase between 900 and 1,200 feets and then decrease.

\subsection{Geochemistry}

The geochemical characterization of 19 calcareous rocks of the Cogollo Group was performed, which was evaluated using three criteria: quantity of organic matter, quality of organic matter and the degree of thermal maturity. The results of TOC determination and Pyrolysis Rock Eval analysis of 19 calcareous rocks of the Cogollo Group (ANH-CR-Montecarlo$1 \mathrm{X}$ well) are presented in table 2 .

\section{Discussion}

\subsection{Diagenetic evolution}

\subsubsection{Siliciclastic rocks}

The diagenetic mineral association found in the sedimentary rocks of the ANH-CR-Montecarlo-1X well can be assigned to the stages of eogenesis and

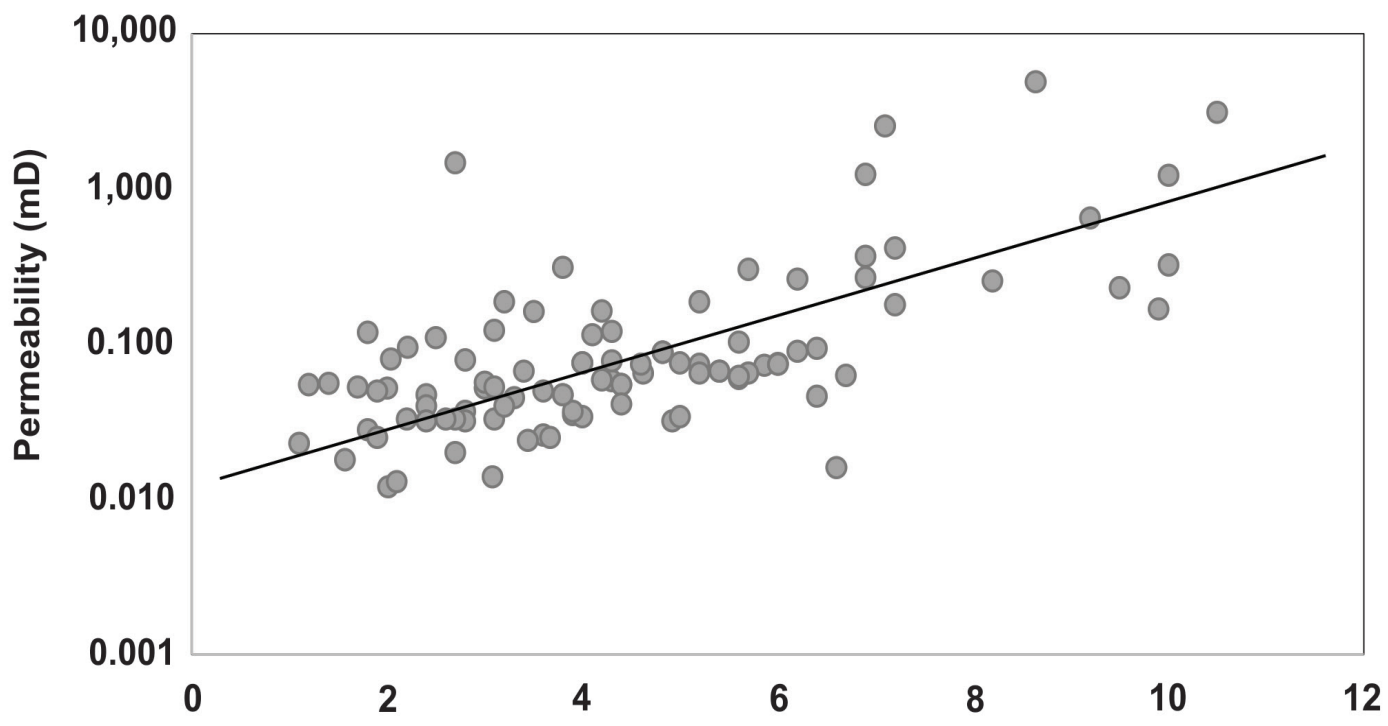

FIG. 9. Scatterplot porosity versus permeability for ANH-CR-Montecarlo-1X well. 

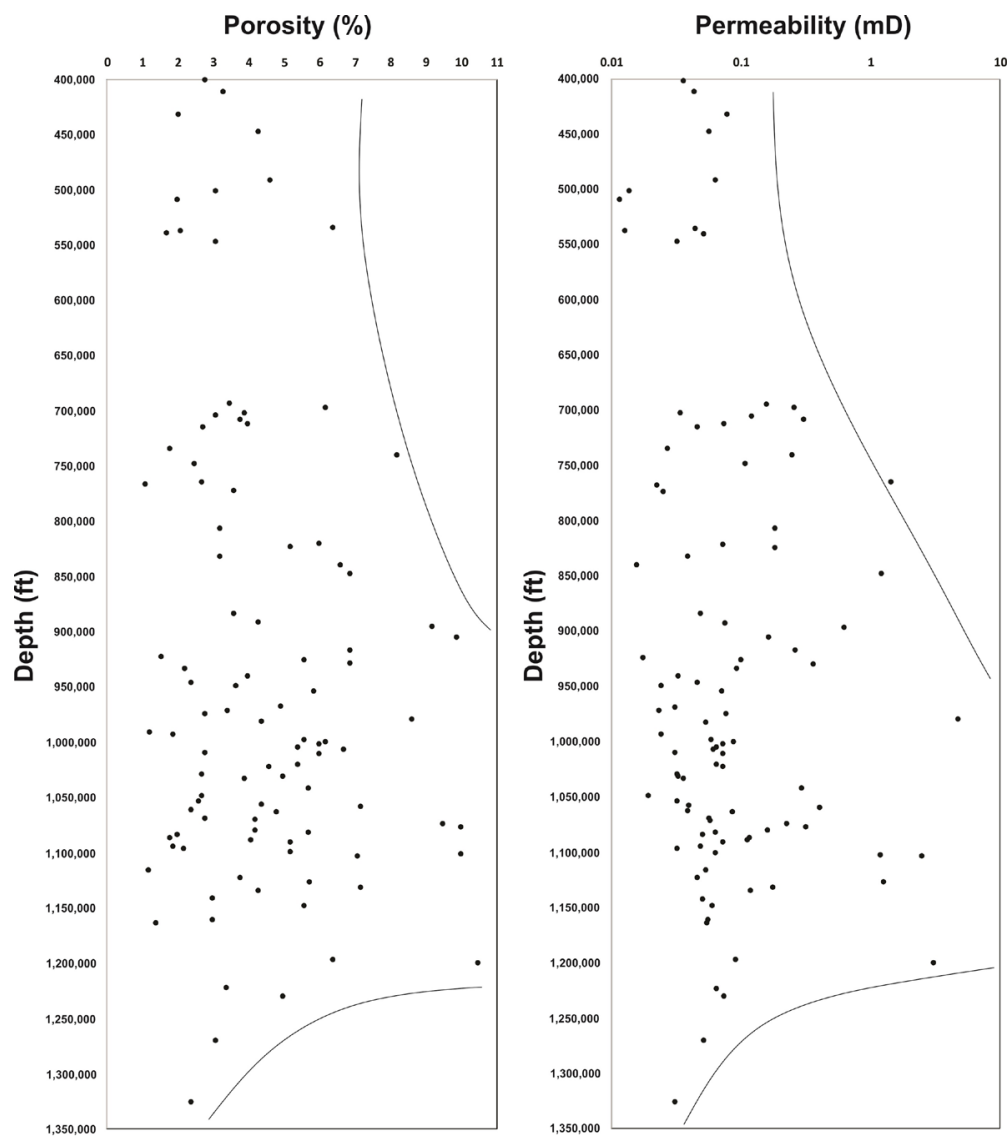

FIG. 10. Porosity and permeability versus depth for ANH-CR-Montecarlo-1X well.

mesogenesis of Worden and Burley (2003). The first occurs at shallow depths $\left(\right.$ e.g., $<2 \mathrm{~km}$ and $\left.<70{ }^{\circ} \mathrm{C}\right)$ and the second at deeper burial depth and higher temperatures.

The classification of diagenetic products and processes within the stages of eogenesis and mesogenesis is based on previous studies (e.g., Morad et al., 2000; Worden and Burley, 2003; Boggs, 2009; Schrank and De Ros, 2015). Figure 11 shows the sequence of diagenetic events according to the main processes and diagenetic products observed in the Cogollo Group sandstones present in the ANHCR-Montecarlo-1X well, and a schematic burial diagram for the Cesar sub-basin in the study area, taken from García and Umaña (2007) and Chajín Ortiz and Martínez Lugo (2008).

The siliciclastic rocks of the Cogollo Group were deposited in a marine environment, so during the eogenesis, the pore waters were highly salty which influences processes such as dissolution of unstable grains like plagioclase (Fig. 4) (Gómez-Peral, 2008). The order that mineral precipitation is commonly reported during eogenesis is: pyrite formation, ironrich chlorite formation (chamosite), illite/smectite minerals (Fig. 5T), clayey minerals (Figs. 5C, D, S, T), quartz overgrowth (Figs. 5A, B, Q) and carbonate cement precipitation (Fig. 5E, H, U) (e.g., Morad et al., 2000; Worden and Burley, 2003; Boggs, 2009; Schrank and De Ros, 2015). On the other hand, during the mesogenesis due to the burial there is an increase in temperature, and concentration of silica in the poral water and precipitation together with the compaction, which produces a decrease of the porosity (Figs. 5A, B, Q) (e.g., Lai et al., 2016). In addition to an increase in temperature and pressure, in mesogenesis the composition of the pore water changes due to water/minerals interaction. The presence of organic matter during the burial also affects mesogenesis, generating thermal decarboxylation that destroys 
TABLE 2. GEOCHEMICAL DATA OBTAINED BY PYROLYSIS ROCK-EVAL AND TOC ANALYSIS.

\begin{tabular}{|c|c|c|c|c|c|c|c|c|}
\hline Depth (ft) & $\begin{array}{c}\text { Total } \\
\text { organic } \\
\text { carbon } \\
(\mathrm{TOC}) \\
\%[\mathrm{p} / \mathrm{p}]\end{array}$ & $\begin{array}{l}\text { S1 (mg } \\
\text { HC/g } \\
\text { sample) }\end{array}$ & $\begin{array}{c}\text { S2 (mg } \\
\text { HC/g } \\
\text { sample) }\end{array}$ & $\begin{array}{c}\mathrm{S} 3 \text { (mg } \\
\mathrm{CO}_{2} / \mathrm{g} \\
\text { sample) }\end{array}$ & $\begin{array}{c}\mathrm{T}^{\circ} \mathbf{m a x} \\
\left({ }^{\circ} \mathrm{C}\right)\end{array}$ & $\begin{array}{c}\text { Hydrogen } \\
\text { index (HI) } \\
\text { (mg HC/g } \\
\text { TOC) }\end{array}$ & $\begin{array}{c}\text { Oxygen index } \\
\text { (OI) (mg } \\
\mathrm{CO}_{2} / \mathrm{g} \text { TOC) }\end{array}$ & $\begin{array}{l}\text { Production } \\
\text { index }\end{array}$ \\
\hline 125.58 & 4.50 & 0.16 & 0.97 & 0.25 & 550.00 & 21.57 & 5.56 & 0.14 \\
\hline 192.83 & 0.11 & 0.20 & 0.19 & 0.15 & 367.50 & 169.72 & 137.61 & 0.51 \\
\hline 256.50 & 0.11 & 0.17 & 0.16 & 0.16 & 353.50 & 137.17 & 141.59 & 0.52 \\
\hline 295.75 & 0.45 & 0.22 & 0.15 & 0.22 & 353.00 & 33.04 & 48.46 & 0.59 \\
\hline 319.50 & 0.16 & 0.07 & 0.09 & 0.15 & 348.50 & 52.80 & 93.17 & 0.45 \\
\hline 339.67 & 0.16 & 0.12 & 0.14 & 0.20 & 347.50 & 85.44 & 126.58 & 0.47 \\
\hline 355.17 & 0.22 & 0.19 & 0.14 & 0.14 & 349.00 & 62.50 & 62.50 & 0.58 \\
\hline 528.27 & 0.03 & 0.29 & 0.18 & 0.08 & 351.00 & 0.00 & 0.00 & 0.62 \\
\hline 550.75 & 1.01 & 0.22 & 0.26 & 0.16 & 526.50 & 25.67 & 15.79 & 0.46 \\
\hline 589.50 & 0.32 & 0.28 & 0.18 & 0.20 & 355.50 & 56.25 & 60.94 & 0.61 \\
\hline 605.42 & 0.19 & 0.20 & 0.17 & 0.23 & 360.00 & 91.89 & 124.32 & 0.54 \\
\hline 608.40 & 0.23 & 0.20 & 0.11 & 0.17 & 348.50 & 48.25 & 74.56 & 0.64 \\
\hline 609.33 & 0.15 & 0.23 & 0.15 & 0.19 & 358.00 & 102.04 & 125.85 & 0.60 \\
\hline 626.33 & 0.19 & 0.19 & 0.13 & 0.17 & 351.50 & 67.01 & 85.05 & 0.59 \\
\hline 636.30 & 4.35 & 0.56 & 0.23 & 0.20 & 358.50 & 5.18 & 4.49 & 0.71 \\
\hline 667.60 & 1.07 & 0.21 & 0.19 & 0.14 & 353.00 & 17.27 & 12.61 & 0.53 \\
\hline 726.80 & 0.02 & 0.19 & 0.16 & 0.13 & 353.00 & 0.00 & 0.00 & 0.54 \\
\hline 732.90 & 0.00 & 0.24 & 0.17 & 0.12 & 350.50 & 0.00 & 0.00 & 0.59 \\
\hline 785.50 & 0.26 & 0.39 & 0.16 & 0.14 & 353.50 & 59.85 & 52.12 & 0.71 \\
\hline
\end{tabular}

carboxylic acids and that produces acidic water causing precipitation of carbonates (Figs. 5E, H, U) (e.g., Boggs, 2009; Xi et al., 2015; Lai et al., 2016). Cementation and compaction of the siliciclastic rocks. The cementation process (Fig. 5) begins during eogenesis with the precipitation of authigenic clay minerals, overgrowth of silica and carbonate cement and continues during the mesogenesis and may even occur in telogenesis (Morad et al., 2000; Boggs, 2009). If the cementation occurs in early stages before a significant compaction, it can inhibit the compaction of the sediments in addition to the flow of fluids through the sediments (Boggs, 2009), aspect that was not evidenced in the rocks of the present study due to the low content of precipitated cement. Numerous processes have been suggested for quartz precipitation (Fig. 5A, B, Q), but in general any mechanism that increases the concentration of silica in the pore water above the equilibrium concentration can cause precipitation (Morad et al., 2000; Boggs, 2009). Similarly, there are many possible sources of silica for quartz cementation to occur; the most important source is the solution pressure of quartz grains at contact points, under conditions of intermediate to deep depths during mesogenesis (Kim and Lee, 2004; Boggs, 2009). The highest silica cementation in the rocks of study area probably occurs during eodiagenesis and early mesodiagenesis, and the precipitation rate of silica cement increases exponentially with temperature, evidenced in in this case by the increasing amounts of silica cement as the depth increases (Fig. 6) (Boggs, 2009; Worden and Burley, 2003; Schrank and De Ros, 2015). According to Boggs (2009), carbonate precipitation (Fig. 5E-H, U) occurs when the solubility of calcium carbonate in pore waters decreases in a saturated carbonate system. The solubility may decrease as result of an increase in the concentration of calcium or bicarbonate ions, increase in temperature, or decrease in $\Sigma \mathrm{CO}_{2}$, which may occur from the earliest 


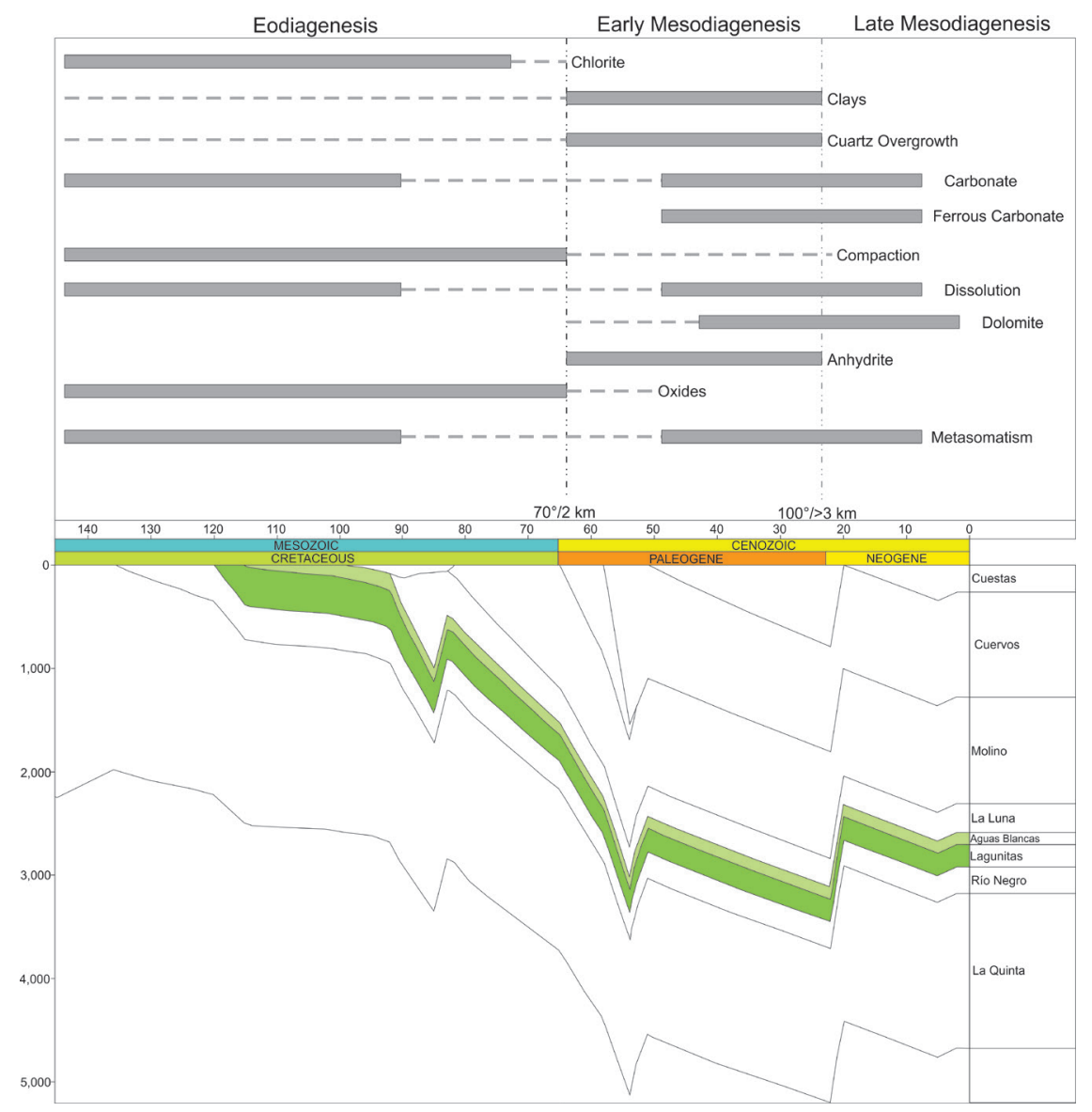

FIG. 11. Upper panel: Sequence of diagenetic events for the siliciclastic rocks studied. Lower panel: Schematic burial diagram for the study area. Adapted and modified by García and Umaña (2007) and Chajín Ortiz and Martínez Lugo (2008).

stages (eogenesis) in the ANH-CR-Montecarlo-1X rocks (e.g., Morad et al., 2000; Worden and Burley, 2003; Boggs, 2009; Schrank and De Ros, 2015). The presence of organic matter during the burial (mesogenesis) and its reactions generate thermal decarboxylation that destroys the carboxylic acids and produces acidic water causing the precipitation of carbonate cement (Boggs, 2009; Xi et al., 2015; Lai et al., 2016). In the case of dolomite cement (Fig. 5K, L, V), with the increase in temperature $\left(60^{\circ}\right.$ or more) in the mesodiagenesis the magnesium and $\mathrm{Fe}$ ions (which are stable in the eogenesis) precipitate in carbonate cements of magnesium and iron type (dolomite, ankerite and siderite) (Boggs, 2009; Xi et al., 2015). Regarding the behavior of clay mineral during the diagenesis (Fig. 5C, D, S, T), Houseknecht and Pittman (1992) indicate that the clay minerals are influenced by temperature and by organic and inorganic reactions that affect the composition of pore water. The increase in temperature generally promotes the generation of clay minerals, although it is known that some clay minerals such as kaolinite are formed at both low and high temperatures. In that sense, different authigenic clay minerals precipitate at different temperatures and depths, then they are found throughout all stages of diagenesis. Regarding the clays reported in the present study (Fig. 6) (illita, smectite and its interstratified) they are common in the studied section and display an increase in abundance with depth. Morad et al. (2000) and Boggs (2009) indicate that this occur during mesogenesis. Anhydrite (Fig. 5M, N, W) is commonly associated with environments with large amounts of dissolved salts, where it precipitates as cement in shallow burial depths (early mesogenesis) as is the case in the present study (Morad et al., 2000; Boggs, 2009). Authigenic 
iron oxides and oxidation of ferromagnesian grains (Fig. 5O, P, X) occur particularly at shallow depths in the presence of meteoric waters, but they can occur at any depth where oxidizing waters occur. The destruction of detritic grains by oxidation is more common during eogenesis and telogenesis (El-Ghali et al., 2006; Boggs, 2009). In the compaction process of the sedimentary rocks, resulting from the burial of the sedimentary pile, causes the rock fabric/ texture becomes a tight packing which leads to the reduction of the porosity. Mechanical compaction occurs at burial depths close to $1,000 \mathrm{~m}$ and chemical compaction (solution pressure) from 500 to $4,500 \mathrm{~m}$. Mineral alteration during the diagenesis. The processes of metasomatism or replacement (Fig. 7) can occur in all stages of diagenesis (Morad et al., 2000). In the present study the petrographic evidence indicates that during the diagenetic processes carbonates, clay minerals and feldspars were the most affected by the metasomatic processes. Clay minerals were replaced by chlorite during the early diagenesis (eogenesis) and feldspars were replaced by cabonates and sericite-illite in the mesogenesis.

\subsubsection{Carbonatic rocks}

According to Boggs (2009), unlike siliciclastic rocks, whose diagenesis is more intense during deep burial, important diagenetic transformations occur within the first kilometer of burial. This is due to the higher solubility and reaction rate of carbonates with respect to silicates, which explains that in carbonates the equilibrium tends to be reached more quickly than in siliciclastic rocks. Another reason is that carbonates are already in a state of partial equilibrium with the waters where they have precipitated, while siliciclastic sediments are made up of allochthonous components. In general, carbonate minerals are more susceptible to diagenetic changes such as dissolution, recrystallization and replacement than silicate minerals (Boggs, 2009). Figure 12 illustrates the main diagenetic processes identified in the carbonate rocks of the study area. These include

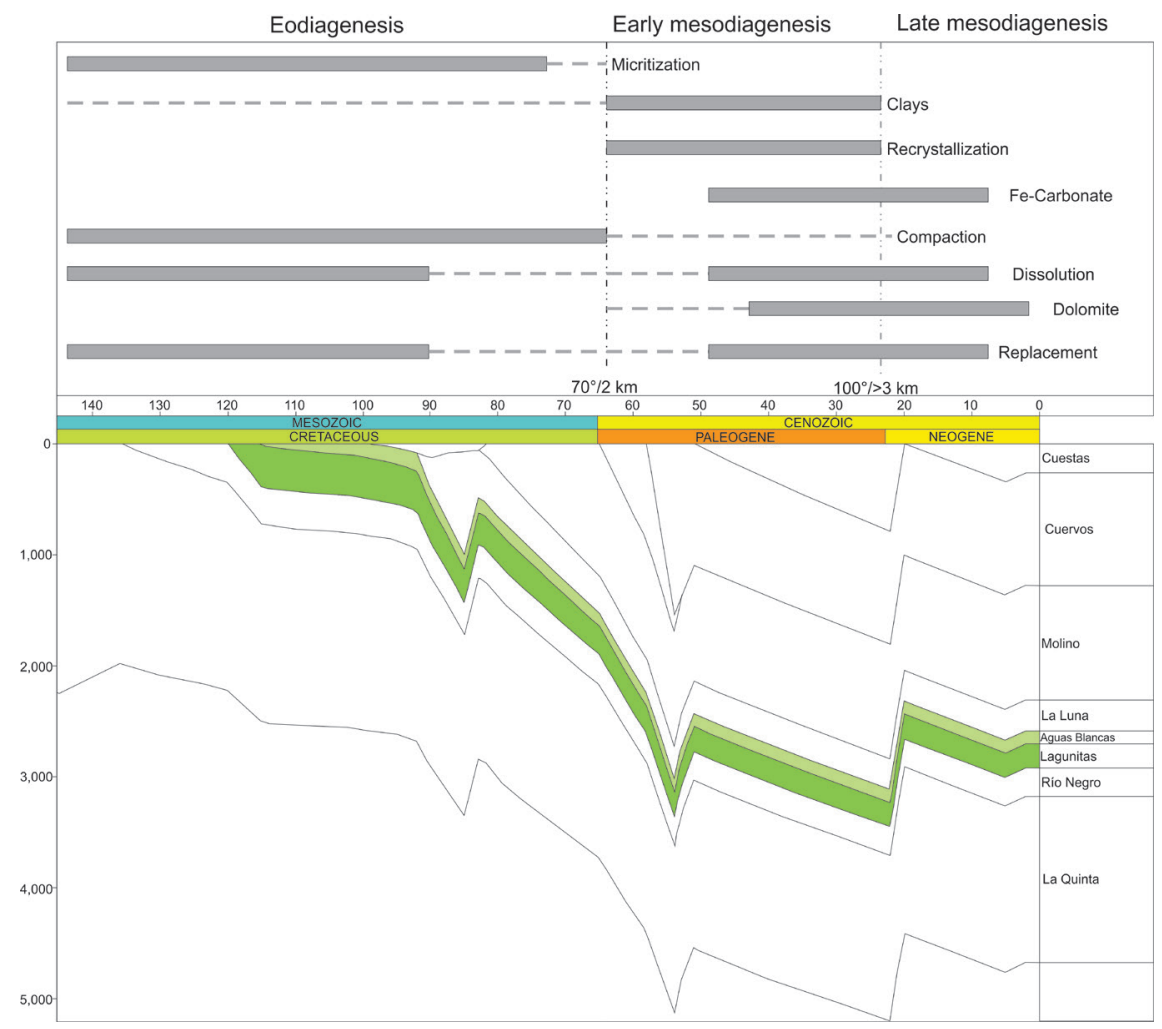

FIG. 12. Upper panel: Sequence of diagenetic events for the carbonate rocks studied. Lower panel: Schematic burial diagram for the study area. Adapted and modified by García and Umaña (2007) and Chajín Ortiz and Martínez Lugo (2008). 
recrystallization from micrite to sparite (Fig. 8A-E) and carbonate cementation (Fig. 8G-J), processes that occur mainly during eogenesis (e.g., Boggs, 2009; Guzmán-Cardona et al., 2010; Moore, 2013).

According to Boggs (2009) and GuzmánCardona et al. (2010), during early marine diagenesis, microbial micritization, mechanical deformation occurs (Fig. 8O-P), as well as basal and carbonate pore cements (Fig. 8G-J). During late burial diagenesis, metasomatisms, neomorphisms (Fig. 8A-E), dissolution pressure structures, overgrowths, mosaic cements, dolomitization and basal poikilitic cement occur. Carbonate sediments undergo several diagenetic modifications during their burial that can reduce or improve their porosity. As with siliciclastic rocks, compaction and cementation reduce porosity, while on the contrary, dissolution increases it (e.g., Gómez-Peral, 2008; Boggs, 2009). In addition, there is usually a tendency that as the depth increases, the porosity of the rock decreases. The sequence of events proposed for the calcareous rocks of the Cogollo Group is as follows: clays precipitation, micritization, replacement of fossil shells by sparite, dissolution, dolomitization and replacement of feldspars to carbonate. Montealegre et al. (2013) indicate that the diagenesis processes of the cabonate rocks of de Cogollo Group, in the Cesar-Ranchería basin, mainly caused fossil replacement by sparite, stylolitization, dolomitization and sutured, concaveconvex and floating grain contacts, concluding in a low to medium diagenetic involvement (eogenesis and mesogenesis stages). The diagenetic results of Montealegre et al. (2013) do not differ from the results found in the present investigation.

\subsection{Quality as reservoir rock}

The porosity and permeability of sandstones is controlled by several factors including grain size, precipitation of diagenetic cements, compaction and generation of secondary porosity as suggested by different authors (e.g., Sandoval, 2000; Xi et al., 2015; Lai, et al., 2016; Yuan et al., 2017; Yu et al., 2018). The current reservoir quality is the sum of depositional characteristics and subsequent diagenetic modifications. The Cogollo Group rocks were deposited in conditions of a shallow marine platform environment on average (e.g., Hernández, 2003; Mesa and Rengifo, 2011), undergoing diagenetic modifications at an early stage due to pore water (eogenesis), and later during burial (mesogenesis). Diagenetic processes play a very important role in the post-depositional modification of the porosity, causing a decrease in the porosity as a result of compaction and cementation

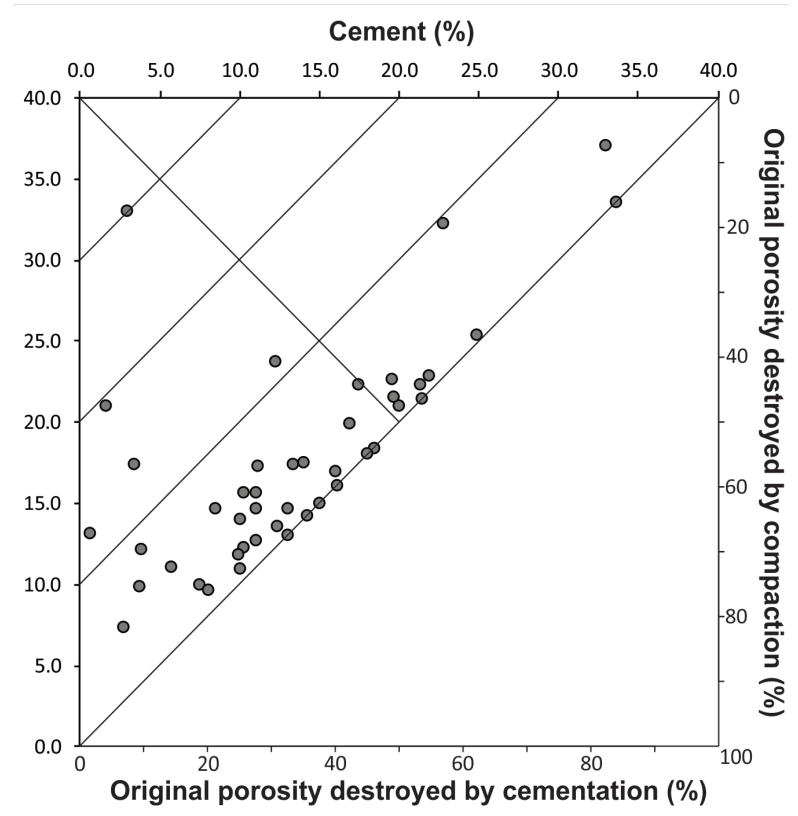

FIG. 13. Diagram of evaluation of the importance of compaction and cementation according to Houseknecht (1987). 
or increase due to dissolution processes. This is why Houseknecht (1987) developed a diagram where he associates porosity with the processes of compaction and cementation, which when plotting the results of the present study show that compaction has been the process of greatest relevance in the loss of porosity, more than cementation (Fig. 13).

The studied rocks have a tight packing with an intergranular volume that varies from 7 to $36 \%$, with an average of 14\% according Houseknecht (1987) diagram (Fig. 13). The initial intergranular porosity decreased due to compaction and cementation and increased due to dissolution of unstable grains. According to Boggs (2009), the primary porosity of sandstones is destroyed at burial depths close to $5,000 \mathrm{~m}$ by the combination of cementation and compaction. In addition to the different diagenetic processes, the proportion of rigid grains (mainly quartz) in sandstones has a major impact on reservoir quality. In the studied rocks, the porosity increases with the amount of quartz grains (Fig. 14A), which suggests that detritic quartz is rigid and
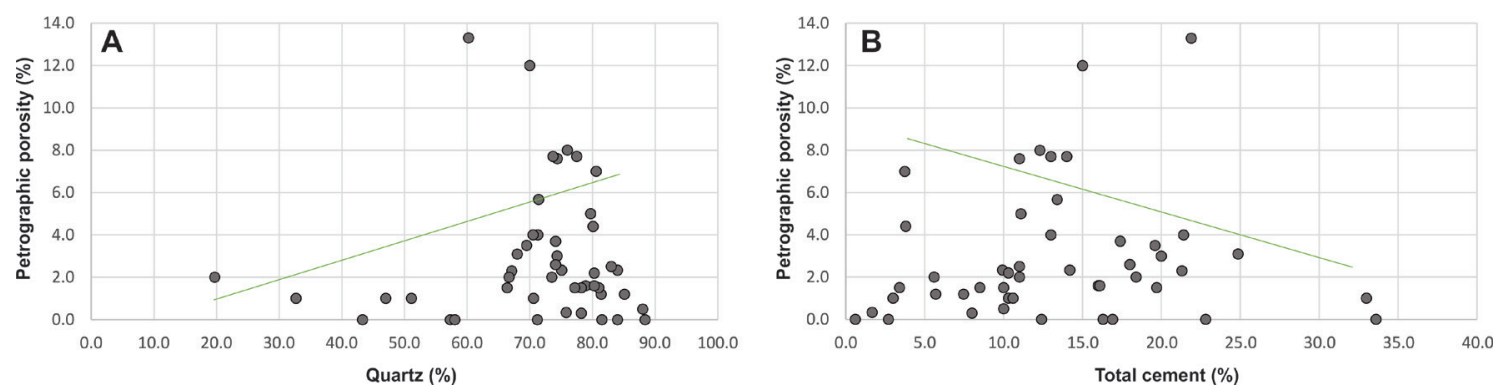

FIG. 14. A. Quartz diagram versus petrographic porosity. B. Total cement diagram versus petrographic porosity according to Bloch et al. (2002); Lai et al. (2016); Yu et al. (2018).

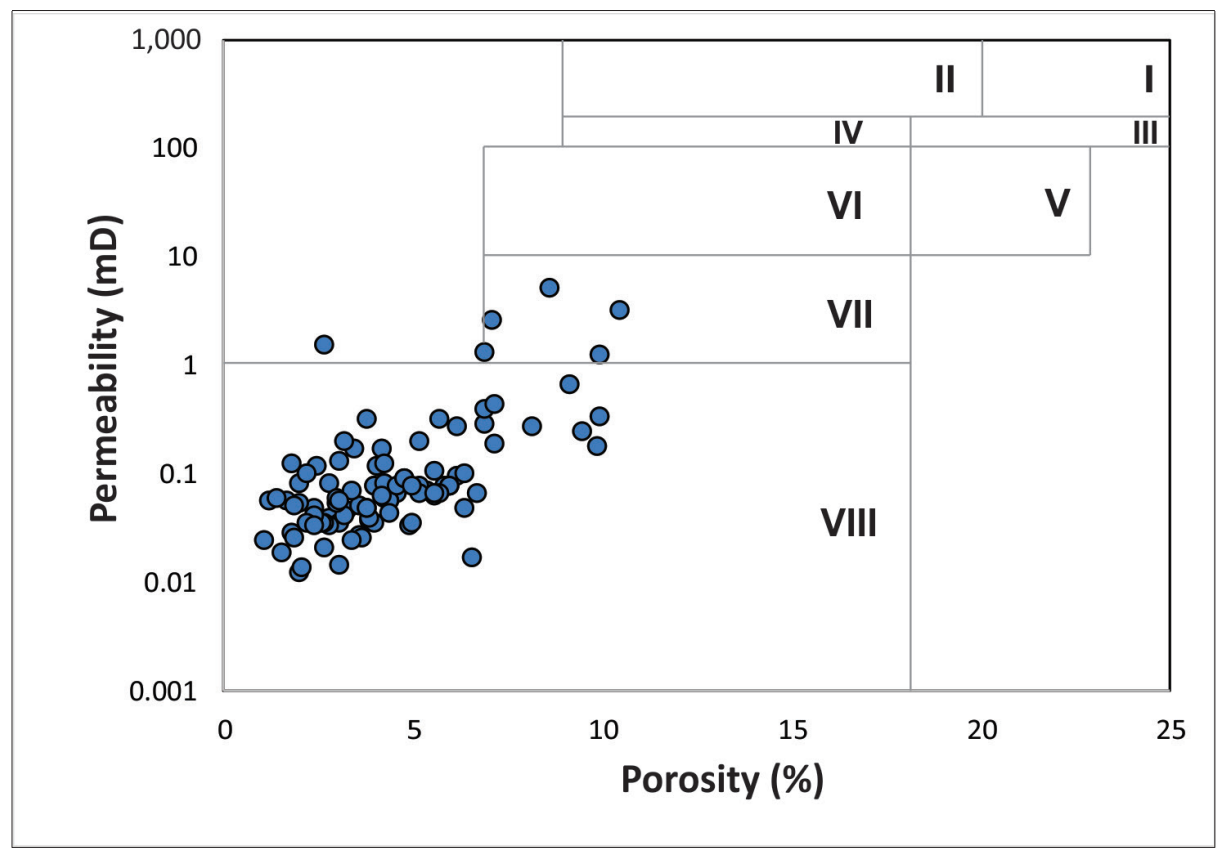

FIG. 15. Porosity versus permeability diagram with the reservoir quality classification according to Shogenov et al. (2015) for the rocks of the present study. 
resistant to compression during progressive burial and compaction (Bloch et al., 2002; Lai et al., 2016; Yu et al., 2018). In the study area, the petrographic porosity of the rocks increases when the amount of cement decreases (Fig. 14B), which is consistent, since cement precipitation is one of the main occluders of porosity in the rocks.

According to the permeability and porosity data of the studied rocks (Fig. 15) plotted in the classification scheme proposed by Shogenov et al. (2015), It is observed that the rocks of the Cogollo Group are classified as reservoirs of low porosity (Class VII, 1-10 mD of permeability and 7-18\% of porosity) to very low porosity (Class VIII, $<1 \mathrm{mD}$ of permeability and $<18 \%$ of porosity). According to the classification of Zou et al. (2012), it is observed that the Cogollo Group siliciclastic rocks meet all the criteria to be classified as tight sand reservoirs (medium diagenetic evolution, secondary porosity, porosity between $3-12 \%$ and permeabilities less than $0.1 \mathrm{mD}$ ). This in contrast to the classification of a conventional sandstone reservoir made by the same author (late diagenetic evolution, primary porosity, porosity between $12-30 \%$ and permeabilities $>0.1 \mathrm{mD})$.

\subsection{Quantity, quality, thermal maturity and hydrocarbon generation potential}

\subsubsection{Amount of organic matter}

The parameters S2 (mg HC/gTOC) versus TOC were plotted in figure 16A; only four Cogollo Group samples show good to excellent percentages of TOC with most of the samples presenting low TOC content, but with low $\mathrm{S} 2$ values (poor), indicative of the overmaturity of these rocks and because they may have already expelled the hydrocarbons that may have been generated. Mora et al. (2007) and García and Umaña (2007) found good contents of organic matter $(1.47 \%$ average TOC) in rocks of the Animas member of the Aguas Blancas Formation, but low contents $(<1 \%$ TOC and $\mathrm{S} 2<1 \mathrm{mg} \mathrm{HC} / \mathrm{g}$ rock) in rocks of the Tocuy and Maracas members of Aguas Blancas Formation, similar to the results obtained in this work. Aguilera et al. (2010) indicate for the Aguas Blancas and Lagunitas Formations good amounts of organic matter $(0-4 \%$ TOC, 0-10 $\mathrm{mg} \mathrm{HC/g} \mathrm{rock} \mathrm{S2)} \mathrm{as} \mathrm{well} \mathrm{as} \mathrm{Mesa} \mathrm{and} \mathrm{Rengifo}$ (2011) which for the same rock formations indicated TOC values $>1 \%$.

\subsubsection{Potential for hydrocarbon generation}

The diagram $\mathrm{S} 1+\mathrm{S} 2$ (Generation potential) versus \% TOC (Fig. 16B) shows that the Cogollo Group rock samples mostly exhibit low amounts of total organic carbon and low values of generation potential, which suggest that these rocks do not have conditions to be considered as source rocks. Mora et al. (2007) and García and Umaña (2007) defined a low hydrocarbon generation potential for the Tocuy and Maracas members of the Aguas Blancas Formation and the Lagunitas Formation, in contrast to the rocks of the Animas member of the Aguas Blancas Formation which are considered to have hydrocarbon generation potential but which is currently consumed by its thermal state. Aguilera et al. (2010) point out that the rocks of the Aguas Blancas Formation has good hydrocarbon generation potential with values of $\mathrm{HI}<200 \mathrm{mg} \mathrm{H} / \mathrm{g}$ TOC and S2 $>5 \mathrm{mg} \mathrm{HC} / \mathrm{g}$ rock. Mesa and Rengifo (2011) indicate for rocks of the Aguas Blancas Formation good to very good hydrocarbon generation potential with values of $\mathrm{S} 1+\mathrm{S} 2$ that reach $13 \mathrm{mg} \mathrm{HC} / \mathrm{g}$ rock, identifying these as potential source rocks in the Cesar sub-basin.

\subsubsection{Quality of organic matter}

The rock samples of the Cogollo Group, according to the diagram of Van Krevelen (1961) (Fig. 16C), are mostly Type IV or inert due to their maturity, and some become Type III with the potential to generate gas. Mora et al. (2007) and García and Umaña (2007) made studies of VAK (Visual Analysis of the Kerogen) and determined that the kerogen contained in the rocks of the Ánimas member of the Aguas Blancas Formation is mostly composed of amorphous material ( $>90 \%$ ) which would indicate the presence of mainly liquid hydrocarbons and lower proportion of gaseous. In general, for the Cogollo Group sedimentary rocks, the authors obtained type II and III kerogens. According to Aguilera et al. (2010), the kerogens contained in rocks of the Aguas Blancas and Lagunitas formations correspond to type II kerogens, with the potential to generate oil. On the other hand, Mesa and Rengifo (2011) showed for the Cogollo Group rocks presence of kerogens type II/III with the potential to generate both liquid and gaseous hydrocarbons. The results obtained from Kerogens type III and IV are due to the fact that the rocks are located in an area of greater maturity as described by Martínez de Vivas et al. (2012). 

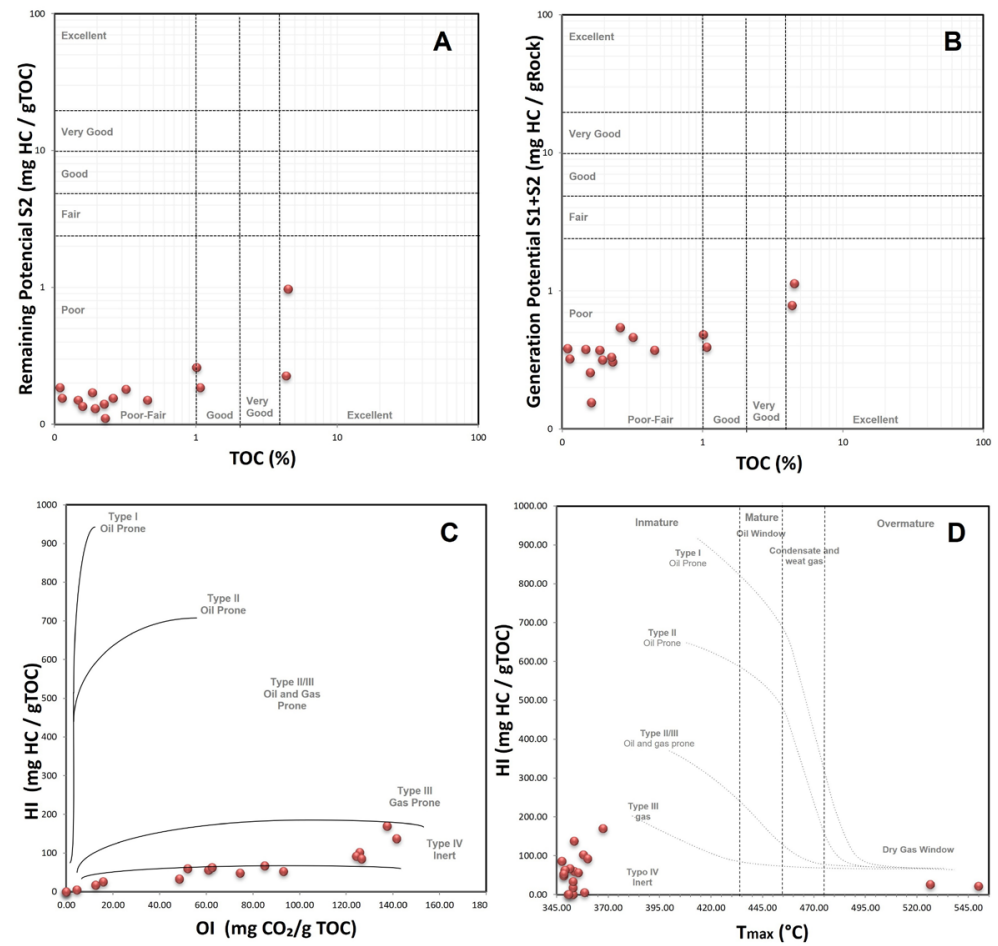

FIG. 16. A. Diagram S2 versus \% TOC of the rock sample values of the present study; B. Diagram S1+S2 versus \% TOC of the rock sample values of the present study; C. Van Krevelen diagram, HI versus OI with the values of the rock samples of the present study; D. HI versus Tmax diagram of the rock sample values of the present study (Van Krevelen,1961).

\subsubsection{Thermal maturity}

The Tmax values obtained for the studied rocks (Fig. 16D) are well below what was expected for these rocks, showing the immature ranges Tmax, in contrast two samples are observed with temperatures higher than $500{ }^{\circ} \mathrm{C}$, indicating that the rocks are possibly overmature in the dry gas window, however, it is recommended for future studies to use other techniques of greater precision to analyze the temperature, such as vitrinite reflectance or spore coloration index. Mora et al. (2007) and García and Umaña (2007) indicated that, according to the parameters of thermal maturity, the rocks of the Cogollo Group currently have a mature state and are depleted in hydrocarbons $(\mathrm{HI}<20 \mathrm{mg} \mathrm{HC} / \mathrm{g}$ TOC). The production index yields values $>0.2$ for the rocks of the Cogollo Group (Mora et al., 2007; García and Umaña, 2007), indicating high levels of conversion of organic matter. Thermal maturity studies by Aguilera et al. (2010) revealed mature and overmature states for rocks of the Aguas Blancas and Lagunitas Formations belonging to the Cogollo Group, with Tmax values of 440 at $550{ }^{\circ} \mathrm{C}$. According to Mesa and Rengifo (2011), the rocks of the Lagunitas and Aguas Blancas Formations are mature to overmatures for the generation of liquid hydrocarbons. Martínez de Vivas et al. (2012) performed 3D modeling for the Cesar-Ranchería basin in order to analyze the generation, migration and accumulation of hydrocarbons. They identified a "trend" of maturity composed of three strips (overmature, mature and immature) for the Mesozoic source rocks (Fig. 1), which has a parallel direction to the axis of the basin and show an increase to the southeast of the basin. In addition, they identified two main pulses for the expulsion of hydrocarbons for the Cesar sub-basin, one in the late Cretaceous and another in the early Eocene. Martínez de Vivas et al. (2012) also concluded that the generation and accumulation of hydrocarbons in conventional reservoirs, and mainly in unconventional reservoirs is ten times larger in the southern sector of the basin (Cesar) than in the northern sector (Ranchería), identifying 
the maturity ranges of liquid-gas (matures) and gas (overmature) as the most likely areas for unconventional hydrocarbons.

\section{Conclusions}

The petrographic study of the Cogollo Group rocks in the ANH-CR-Montecarlo-1X well in the Cesar Ranchería basin revealed that the compositionally predominant rocks correspond to quartz-sandstone and quartz greywackes, and carbonate rocks were mainly classified as allochemical rocks according to the classification of Folk (1974) and according to the Dunham classification (1962) correspond to mudstone, wackestone and packstone. The main diagenetic processes that affect the sandstones and greywackes of the ANH-CR-Montecarlo-IX well are compaction and cementation by quartz and carbonate. And regarding carbonate rocks recrystallization and carbonate cementation are the main diagenetic processes that affect them. In general, the permeability of the rocks was more affected by compaction than cement precipitation. Additionally, the results of the basic petrophysical analyzes, the Cogollo Group rocks present in the ANH-CR-Montecarlo-1X exhibit low potential as a conventional hydrocarbon reservoir but they show a good potential as reservoirs of unconventional hydrocarbons of the tight sands type. Geochemical studies exhibited mainly low content of total Organic Carbon $(<1 \%)$ with a low potential for hydrocarbon generation, with type III and IV kerogens. The rocks have high levels of conversion of organic matter, which indicates that the rocks did generate hydrocarbons, but are currently depleted and in a state of maturity.

\section{Aknowledgements}

This research project was funded by the Agencia Nacional de Hidrocarburos, Departamento Administrativo de Ciencia, Tecnología e Innovación, Universidad Industrial de Santander through the cooperation agreement FP44842-4542017. The present study forms part of the MSc program of M. Vargas. We are indebted to the petrophysics and microscopy laboratories of the Universidad Industrial de Santander and their professional staff for helpful comments, discussion, and assistance with the analytical data acquisition. The manuscript benefited from the constructive comments of anonymous reviewers. We are most grateful to these people and institutions for their support.

\section{References}

Aguilera, R.; Sotelo, V.; Burgos, C.; Arce, C.; Gómez, C.; Mojica, J.; Osorno, J. 2010. Organic Geochemistry Atlas of Colombia. Earth Sciences Research Journal 14: 61-77.

Barrero, D.; Pardo, A.: Vargas, C.; Martínez, J. 2007. Colombian Sedimentary Basins. Agencia Nacional de Hidrocarburos: 92 p. Bogotá.

Bayona, G.; Lamus-Ochoa, F.; Cardona, A.; Montes, C.; Tchegliakova, N. 2007. Procesos orogénicos del Paleoceno para la cuenca de Ranchería (Guajira, Colombia) y áreas adyacentes definidos por análisis de procedencia. Geología Colombiana 32: 21-46. Bogotá.

Bloch, S.; Lander, R.H.; Bonnell, L. 2002. Anomalously high porosity and permeability in deeply buried sandstone reservoirs origin and predictability. American Association of Petroleum Geologists, Bulletin 86 (2): 301-328.

Boggs Jr., S. 2009. Petrology of Sedimentary Rocks. Cambridge University Press: 600 p. Cambridge

Burley, S.D.; Kantorowicz, J.D. 1986. Thin section and SEM textural criteria for the recognition of cementdissolution porosity in sandstones. Sedimentology 33 (4): 587-604.

Chajín Ortiz, P.; Martínez Lugo, A. 2008. Interpretación Sísmica, Estructural y Modelamiento Geoquímico de Dos Líneas Sísmicas en la Subcuenca Cesar (Cuenca Cesar-Ranchería). Ph.D. Thesis (Unpublished), Universidad Industrial de Santander, Escuela de Geología: 152 p.

Dunham, Robert J. 1962. Classification of carbonate rocks according to depositional textures. American Association of Petroleum Geologists (AAPG), Special volume: 108-121. Tulsa.

El-Ghali, M.A.K.; Mansurbeg, H.; Morad, S.; Al-Aasm, I.; Ajdanlisky, G. 2006. Distribution of diagenetic alterations in fluvial and paralic deposits within sequence stratigraphic framework: evidence from the Petrohan Terrigenous Group and the Svidol Formation, Lower Triassic, NW Bulgaria. Sedimentary Geology 190: 1-4.

Folk, R.L. 1974. Petrology of Sedimentary Rocks. Hemphill: 182 p. Austin.

Gao, Y.; Wang, Z.; She, Y.; Lin, S.; Lin, M.; Zhang, C. 2019. Mineral characteristic of rocks and its impact on the reservoir quality of $\mathrm{He} 8$ tight sandstone of Tianhuan area, Ordos Basin, China. Journal of Natural Gas Geoscience 4 (4): 205-214. 
García, M.; Umaña, R. 2007. Prospectividad de la Cuenca Cesar-Ranchería. Agencia Nacional de Hidrocarburos y Universidad Industrial de Santander: 336 p. Bucaramanga.

García, M.; Umaña, R.; Cruz, L.; Vásquez, M. 2009. Evaluación del Potencial Hidrocarburífero de las Cuencas Colombianas. Agencia Nacional de Hidrocarburos y Universidad Industrial de Santander. Informe Ejecutivo: 219 p. Bucaramanga.

Gómez-Peral, L.E. 2008. Petrología y diagénesis de las unidades sedimentarias precámbricas de Olavarría, Provincia de Buenos Aires. Tesis de doctorado (Unpublished), Universidad Nacional de La Plata: 235 p. La Plata.

Guacaneme, C. 2011. Petrografía y Diagénesis a partir de Núcleos de Perforación de las Rocas Sedimentarias de la Cuenca San Juan, Chocó. Tesis de pregrado (Unpublished), Universidad de Caldas: 116 p. Manizales.

Guzmán-Cardona, W.; García-Loaiza, A.M.; RamírezCardona, C. 2010. Estudio Petrográfico y Diagenético de la Secuencia Cenozoica del Cinturón Plegado de San Jacinto y su Aplicación en la Determinación de la Calidad de Reservorios. Universidad Pedagógica y Tecnológica de Colombia, Ingeniería Investigación y Desarrollo 10 (2): 107-127. Tunja.

Haihua, Z.; Guangcheng, L.; Dakang, Z.; Tingshan, Z.; Jun, L.; Jingli, Y. 2018. Diagenetic controls on reservoir quality of tight sandstone: A case study of the Upper Triassic Yanchang formation Chang 7 sandstones, Ordos Basin, China. Earth Sciences Research Journal 22 (2): 129-138.

Hernández, M. 2003. Memoria explicativa de la Plancha 48. Ingeominas: $103 \mathrm{p}$.

Héroux, Y.; Chagnon, A.; Bertrand, R. 1979. Compilation and Correlation of Major Thermal Maturation Indicators. American Association of Petroleum Geologists, Bulletin 63 (12): 2128-2144.

Houseknecht, D.W. 1987. Assessing the relative importance of compaction processes and cementation to reduction of porosity in sandstones. American Association of Petroleum Geologists, Bulletin 71: 633-642.

Houseknecht, D.W.; Pittman E.D. 1992. Origin, Diagenesis, and Petrophysics of Clay Minerals in Sandstones. Society for Sedimentary Geology, Special Publication 47: 288 p. Tulsa.

IAPG. 2019. Hidrocarburos no convencionales. Instituto Argentino del Petróleo y Gas. http:// www.shaleenargentina.com.ar/hidrocarburos-noconvencionales. (Last visited 30/12/2020).
Kareem, R.; Cubillas, P.; Gluyas, J.; Bowen, L.; Greenwell, H.Ch. 2017. Multi-technique approach to the petrophysical characterization of Berea sandstone core plugs (Cleveland Quarries, USA). Journal of Petroleum Science and Engineering 149: 436-455.

Kim, Y.; Lee, Y.I. 2004. Origin of quartz cement in the Lower Ordovician Dongjeom formation, Korea. Journal of Asian Earth Sciences 24 (3): 327-335.

Lai, J.; Wang, G.; Ran, Y.; Zhou, Z.; Cui, Y. 2016. Impact of diagenesis on the reservoir quality of tight oil sandstones: The case of Upper Triassic Yanchang Formation Chang 7 oil layers in Ordos Basin, China. Journal of Petroleum Science and Engineering 145: 54-65.

Lai, J.; Wang, G.; Chai, Y.; Xin, Y.; Wu, Q.; Zhang, X.; Sun, Y. 2017. Deep burial diagenesis and reservoir quality evolution of high-temperature, high-pressure sandstones: Examples from Lower Cretaceous Bashijiqike Formation in Keshen area, Kuqa depression, Tarim basin of China. American Association of Petroleum Geologists, Bulletin 101 (6): 829-862.

Limarino, C.O.; Giordano, S.R.; Albertani, R.J.R. 2017. Diagenetic model of the Bajo Barreal Formation (Cretaceous) in the southwestern flank of the Golfo de San Jorge Basin (Patagonia, Argentina). Marine and Petroleum Geology 88: 907-931.

Ma, P.; Lin, C.; Zhang, S.; Dong, C.; Zhao, Y.; Dong, D.; $\mathrm{Mu}, \mathrm{X} .2018$. Diagenetic history and reservoir quality of tight sandstones: A case study from Shiqianfeng sandstones in upper Permian of Dongpu Depression, Bohai Bay Basin, eastern China. Marine and Petroleum Geology 89: 280-299.

Mahmic, O.; Dypvik, H.; Hammer, E. 2018. Diagenetic influence on reservoir quality evolution, examples from Triassic conglomerates/arenites in the Edvard Grieg field, Norwegian North Sea. Marine and Petroleum Geology 93: 247-271.

Martínez de Vivas, M.; Calderón, W.; Zamora, W.; Rodríguez, I. 2012. Modelamientos Numéricos 3D de Sistemas Petrolíferos en la Cuenca Cesar-Ranchería: Nuevas Ideas Acerca de su Potencial Petrolífero. In Simposio Bolivariano-Exploración Petrolera en las Cuencas Subandinas, No. 11, Actas: cp-330-00016. Cartagena de Indias.

McCarthy, K.; Niemann, M.; Palmowski, D.; Peters, K.; Stankiewicz, C. 2011. La geoquímica básica del petróleo para la evaluación de las rocas generadoras. Oilfield Review, Schlumberger 23 (2): 36-47.

Mesa, A.M.; Rengifo, S. 2011. Petroleum Geology of Colombia. Cesar Ranchería Basin. Agencia Nacional de Hidrocarburos-ANH., 6: 159 p. Bogotá. 
Montealegre, M.; Ocampo, N.; Silva, J.; Rosero, J.; Pardo, A.; Bayona, G.; Lamus, F. 2013. Chemostratigraphy and Characterization Diagenetic of Carbonate Rocks, Colombian NE (Cogollo Gr.). In Latin American Geosciences Student Conference (LAGSC), No. 1. Proceedings: 1-5. Medellín.

Mora, C.; Parra, P.; Navas, G. 2007. Caracterización Geoquímica de Rocas y Crudos en las Cuencas de Cesar-Ranchería, Sinú-San Jacinto, Chocó y Área de Soápaga (Cuenca Cordillera Oriental). Agencia Nacional de Hidrocarburos y GEMS Ltda., Informe final: $638 \mathrm{p}$.

Moore, C. 2013. Carbonate Reservoirs: Porosity and Diagenesis in a Sequence Stratigraphic Framework. Elsevier Science: 460 p. Ámsterdam.

Morad, S.; Al Suwaidi, M.; Mansurbeg, H.; Morad, D.; Ceriani, A.; Paganoni, M.; Al-Aasm, I. 2019. Diagenesis of a limestone reservoir (Lower Cretaceous), Abu Dhabi, United Arab Emirates: Comparison between the anticline crest and flanks. Sedimentary Geology 380: $127-142$.

Morad, S.; Ketzer, J.M.; De Ros, L.F. 2000. Spatial and temporal distribution of diagenetic alterations in siliciclastic rocks: implications for mass transfer in sedimentary basins. Sedimentology 47: 95-120.

Rahman, M.J.J.; McCann, T. 2012. Diagenetic history of the Surma group sandstones (Miocene) in the Surma Basin, Bangladesh. Journal of Asian Earth Sciences 45: 65-78.

Rahman, M.J.J.; Worden, R.H. 2016. Diagenesis and its impact on the reservoir quality of Miocene sandstones (Surma Group) from the Bengal Basin, Bangladesh. Marine and Petroleum Geology 77: 898-915.

Sandoval, M.A. 2000. Diagénesis de Areniscas. Universidad Central de Venezuela, Consejo de Desarrollo Científico y Humanístico: 414 p. Caracas.

Shogenov, K.; Shogenova, A.; Vizika-Kavvadias, O.; Nauroy, J.F. 2015. Reservoir quality and petrophysical properties of Cambrian sandstones and their changes during the experimental modelling of $\mathrm{CO}_{2}$ storage in the Baltic Basin. Estonian Journal of Earth Sciences 64 (3): 199-217.

Schrank, A.B.S.; De Ros, L.F. 2015. Diagenetic processes in cretaceous sandstones from occidental Brazilian Equatorial Margin. Journal of South American Earth Sciences 63: 1-19.

Van Krevelen, D.W. 1961. Coal: Typology, Chemistry, Physics, Constitution. Elsevier Science: 514 p. Ámsterdam.

Vargas, C.A. 2009. Nuevos aportes a la estimación del potencial de hidrocarburos en Colombia. Revista de la Academia Colombiana de Ciencias Exactas, Físicas y Naturales 33 (126): 17-44.

Worden, R.H.; Burley, S.D. 2003. Sandstone diagenesis: the evolution of sand to stone. In Sandstone Diagenesis: Recent and Ancient (Worden, R.H.; Burley, S.D.; editors). Wiley-Blackwell: 3-44.

Xi, K.; Cao, Y.; Jahren, J.; Zhu, R.; Bjørlykke, K.; Haile, B.G.; Hellevang, H. 2015. Diagenesis and reservoir quality of the Lower Cretaceous Quantou Formation tight sandstones in the southern Songliao Basin, China. Sedimentary Geology 330: 90-107.

Yu, X.; Li, S.; Li, S. 2018. Clastic Hydrocarbon Reservoir Sedimentology. Springer: 712 p. Berlín.

Yuan, G.; Cao, Y.; Zhang, Y.; Gluyas, J. 2017. Diagenesis and reservoir quality of sandstones with ancient "deep" incursion of meteoric freshwater - an example in the Nanpu Sag, Bohai Bay Basin, East China. Marine and Petroleum Geology 82: 444-464.

Zou, C. 2017. Unconventional Petroleum Geology. Elsevier Science: 500 p. Ámsterdam.

Zou, C.; Zhu, R.; Liu, K.; Su, L.; Bai, B.; Zhang, X.; Wang, J. 2012. Tight gas sandstone reservoirs in China: characteristics and recognition criteria. Journal of Petroleum Science and Engineering 88: 82-91.

Manuscript received: March 15, 2020; revised/accepted: January 28, 2021; available online: May 31, 2021. 